\title{
The Brazilian Pareiasaur Revisited
}

\author{
Juan C. Cisneros ${ }^{1 *}$, Paula Dentzien-Dias ${ }^{2}$ and Heitor Francischini ${ }^{3}$ \\ ${ }^{1}$ Museu de Arqueologia e Paleontologia, Universidade Federal do Piauí, Teresina, Brazil, ${ }^{2}$ Laboratório de Geologia e \\ Paleontologia and Programa de Pós-graduação em Oceanologia, Instituto de Oceanografia, Universidade Federal do Rio \\ Grande, Rio Grande, Brazil, ${ }^{3}$ Laboratório de Paleontologia de Vertebrados, Departamento de Paleontologia e Estratigrafia, \\ Instituto de Geociências, Universidade Federal do Rio Grande do Sul, Porto Alegre, Brazil
}

\section{OPEN ACCESS}

Edited by:

Sean P. Modesto,

Cape Breton University, Canada

Reviewed by:

Michael James Benton, University of Bristol, United Kingdom

Marc Johan Van Den Brandt, Wits University, South Africa

*Correspondence:

Juan C. Cisneros

juan.cisneros@ufpi.edu.br

Specialty section:

This article was submitted to

Paleontology,

a section of the journal

Frontiers in Ecology and Evolution

Received: 15 August 2021

Accepted: 21 October 2021

Published: 17 November 2021

Citation:

Cisneros JC, Dentzien-Dias P and Francischini $H$ (2021) The Brazilian

Pareiasaur Revisited.

Front. Ecol. Evol. 9:758802. doi: 10.3389/fevo.2021.758802
Provelosaurus americanus is the only known representative of the Pareiasauria in the Americas. This mid-size pareiasaur from the Rio do Rasto Formation of southern Brazil has been traditionally considered to be related to smaller forms from the South African Karoo known as the "dwarf pareiasaurs" of Lopingian age. P. americanus, however, coexisted with dinocephalians, which indicates a Guadalupian age. New fossils provide a nearly complete osteological account that forms the basis for a revised diagnosis and a test of phylogenetic relationships of $P$. americanus. Our results offer further support to the hypothesis that the Brazilian pareiasaur is the sister taxon of the Karoo "dwarf pareiasaurs," being the earliest member of this group and one of the oldest pareiasaurs known so far. This is reinforced by a radiometric dating of the Morro Pelado Member of the Rio do Rasto Formation. In addition, the association of four individuals of various ontogenetic stages at the type locality supports some degree of social behavior in P. americanus.

Keywords: Parareptilia, Pareiasauria, Permian, Paraná basin, Rio do Rasto Formation, Gondwana

\section{INTRODUCTION}

Pareiasaurs are a successful clade of large herbivorous parareptiles that achieved global distribution throughout the Permian, with oldest records in the Guadalupian, having survived the late Capitanian mass extinction (Day et al., 2015; Day and Rubidge, 2021) and finally becoming extinct during the end-Permian great biotic crisis. Pareiasaurs have been studied since the mid 19th century (see Tsuji and Müller, 2008) and are easily recognizable among contemporaneous tetrapods by a suit of morphological features that include a sculptured, helmet-like anapsid skull with multicusped, leaf-shaped marginal teeth and dermal armor. Pareiasaurs represent the reptiles with the largest body-size in the Permian, and included the first tetrapod species with a fully upright limb posture (Turner et al., 2015). Small forms like Nanoparia luckhoffi were size-equivalent to a living giant armadillo and large species such as Bradysaurus baini and Scutosaurus karpinskii had a mass comparable to a domestic bull, the latter with an estimated weight of up to 1.5 tons (Romano et al., 2021). They have been recorded in Brazil (Araújo, 1985b; Cisneros et al., 2005), South Africa (Rubidge, 2005; Van den Brandt et al., 2021a), Zambia (Lee et al., 1997), Niger (Tsuji et al., 2013), Tanzania (Maisch and Matzke, 2019), Morocco (Jalil and Janvier, 2005), Scotland (Spencer and Lee, 2000), Germany (Tsuji and Müller, 2008), Italy (based on footprints, Leonardi et al., 1974), Russia (Ivakhnenko, 1987; Bulanov and Yashina, 2005; Tsuji, 2013), and China (Li and Liu, 2013; Xu et al., 2014; Benton, 2016; Liu and Bever, 2018). Despite being relatively common in the geological record, specially in the Karoo Basin, their taxonomy and interrelationships have long been problematic, in part because their cranial sutural patterns are typically obscured by thick ornamentation. 
The Rio do Rasto Formation (Paraná Basin) in southern Brazil has produced a tetrapod fauna that shares similarities with both South African and Russian continental assemblages of Guadalupian to Lopingian age (Barberena et al., 1985; Cisneros et al., 2012). Tetrapods are rare and usually represented by single specimen finds. These include anomodonts (Cisneros et al., 2011; Boos et al., 2013, 2016), dinocephalians (Langer, 2000; Cisneros et al., 2012; Boos et al., 2015) and various temnospondyls (Barberena, 1998; Dias and Barberena, 2001; Strapasson et al., 2014; Pacheco et al., 2017; Dias et al., 2020). Apart from fragmentary material attributed to Archosauromorpha (Martinelli et al., 2017) and the occurrence of the ichnogenus Rhynchosauroides in a single locality (Silva et al., 2012), the only reptile recorded in this formation is the mid-sized pareiasaur Provelosaurus americanus. The only South American pareiasaur described so far, it is known from adult and juvenile specimens, being of particular interest because it is considered to belong to the clade informally known as the "dwarf pareiasaurs" (Lee, $1997 b)$. This is a group of smaller forms with higher number of tooth cusps, gracile humerus and ilium, and usually having a well developed dermal armor, once thought to be phylogenetically related to early chelonians (Lee, 1997b). The "dwarf pareiasaurs" are represented by Nanoparia luckhoffi, Anthodon serrarius, and Pumiliopareia pricei, all from the Lopingian of the South African Karoo Basin (Rubidge et al., 2013; Smith, 2020; Viglietti, 2020) and potentially also by Shihtienfenia permica from the Lopingian of China (Liu and Bever, 2018). Paradoxically, Provelosaurus americanus is one of the oldest members of Pareiasauria, considered to be of Guadalupian age due to its coexistence with dinocephalians (Cisneros et al., 2005).

Here we present new specimens of the enigmatic Brazilian pareiasaur. The study of the new fossils and a review of the previously described material offer a comprehensive account of the osteology of Provelosaurus americanus and provide an opportunity to test its relationships with the "dwarf pareiasaurs". The new finds also allow us to address the age and paleoecological significance of this species in the Rio do Rasto Formation of southern Brazil.

\section{GEOLOGICAL SETTING AND STUDY AREA}

The Paraná Basin is a large intracratonic South American basin that covers an area of around 1.4 million $\mathrm{km}^{2}$ that is comprised of Ordovician to end-Cretaceous strata (Milani et al., 2007). The Permian deposits were formed in the context of the epeiric Irati sea, with coastal and marine environments, being represented by the Gondwana I Supersequence (Milani et al., 2007; Holz et al., 2010; Kern et al., 2021). By the middle Permian, this inland sea was isolated from the ocean (Teresina Formation) and a change in the depositional system occurred toward a progressive continentalization and desertification (Rio do Rasto and "Pirambóia" formations) (Zerfass et al., 2003; Kern et al., 2021).

The 400 m-thick Rio do Rasto Formation is subdivided into two members (Gordon, 1947) that reflect different depositional environments: the lower Serrinha Member represents a shallow marine setting and the Morro Pelado Member comprises deltaic and fluvio-lacustrine environments. The latter produces tetrapods and the fossils studied herein, and is characterized by reddish siltstones interbedded by lenticular sandstones and conglomerates (Holz et al., 2010; Kern et al., 2021). These deposits are interpreted as a deltaic system associated with lacustrine and, in the upper part, eolian dune systems (Kern et al., 2021).

The main Rio do Rasto fossil vertebrate areas are located in the Aceguá and São Gabriel municipalities of the Rio Grande do Sul State (Figure 1), and in the Serra do Cadeado region in the Paraná State. In addition to vertebrate remains and trace fossils (see below), the Aceguá region records at least five occurrences of ash fall layers, representing a long-distance expression of the late Paleozoic-Early Triassic Choiyoi volcanism event (Francischini et al., 2018). A Guadalupian age is broadly accepted for these outcrops based on biostratigraphic correlations using tetrapods, although there are some incongruences (Cisneros et al., 2005; Boos et al., 2013; Martinelli et al., 2017; see discussion below). In addition, two of them were recently dated and provided geochronological ages of $270.61+1.76 /-3.27 \mathrm{Ma}$ (Roadian; outcrop tentatively assigned to the Serrinha Member by Francischini et al., 2018) and $266 \pm 5.4 \mathrm{Ma}$ (Wordian, Morro Pelado Member, Rocha-Campos et al., 2019).

Provelosaurus americanus remains were found only at the Rio Grande do Sul state (Figure 1A). The most important site consists of two small, nearby road-cuts along the BR-153 highway (Figure 2), in the Minuano district within the municipality of Aceguá, near the Brazil-Uruguay border. The holotype UFRGSPV-0231-P was found at a small ravine at $\mathrm{km} \mathrm{665.4,} \mathrm{on} \mathrm{the} \mathrm{west}$ side of the road (Figure 1B, site 6, formerly km 204, Araújo, $1985 b)$, which is a sequence of reddish massive/poorly laminated siltstone intercalated by lenses of mudstones and small packages of fine sandstones (Figure 2A), interpreted as a lacustrine environment. The specimen UFRGS-PV-0232-P and two new fossils described here (UFRGS-PV-0358-P and UFRGS-PV-0376P) were also collected at the type locality. Only Provelosaurus americanus remains have been recovered from this outcrop so far.

The second exposure is located $600 \mathrm{~m}$ south of the type locality, at $\mathrm{km} \mathrm{666,} \mathrm{east} \mathrm{side} \mathrm{of} \mathrm{the} \mathrm{road} \mathrm{(formerly} \mathrm{km}$ $204+400 \mathrm{~m}$, Araújo, 1985b) (Figure 1B, site 7), is a large package of massive siltstone interbedded by lenses and small sandstone beds (Figure 2B). It is interpreted as a lacustrine environment crossed by small distributary channels. At the base of this quarry there is a $30 \mathrm{~cm}$ thick layer of bentonite dating of $266 \pm 5.4 \mathrm{Ma}$ (Rocha-Campos et al., 2019). The skeleton UFRGS-PV-0233-P (Araújo, 1985b) and some fish bone and scale remains (UFRGS-PV-0242-P) were recovered from this quarry. The precise stratigraphic level of these fossils were, unfortunately, not recorded by the collectors and their placement in our stratigraphic log is tentative.

The outcrop located at the Santo Antônio Farm (Figure 1B, site 9) is an exposure made during the construction of a water dam. The fossil site is located at the east side of the dam. It consists of a sequence of massive/poorly laminated siltstone intercalated by small conglomerate levels and massive sandstone interpreted as lacustrine and fluvial deposits 

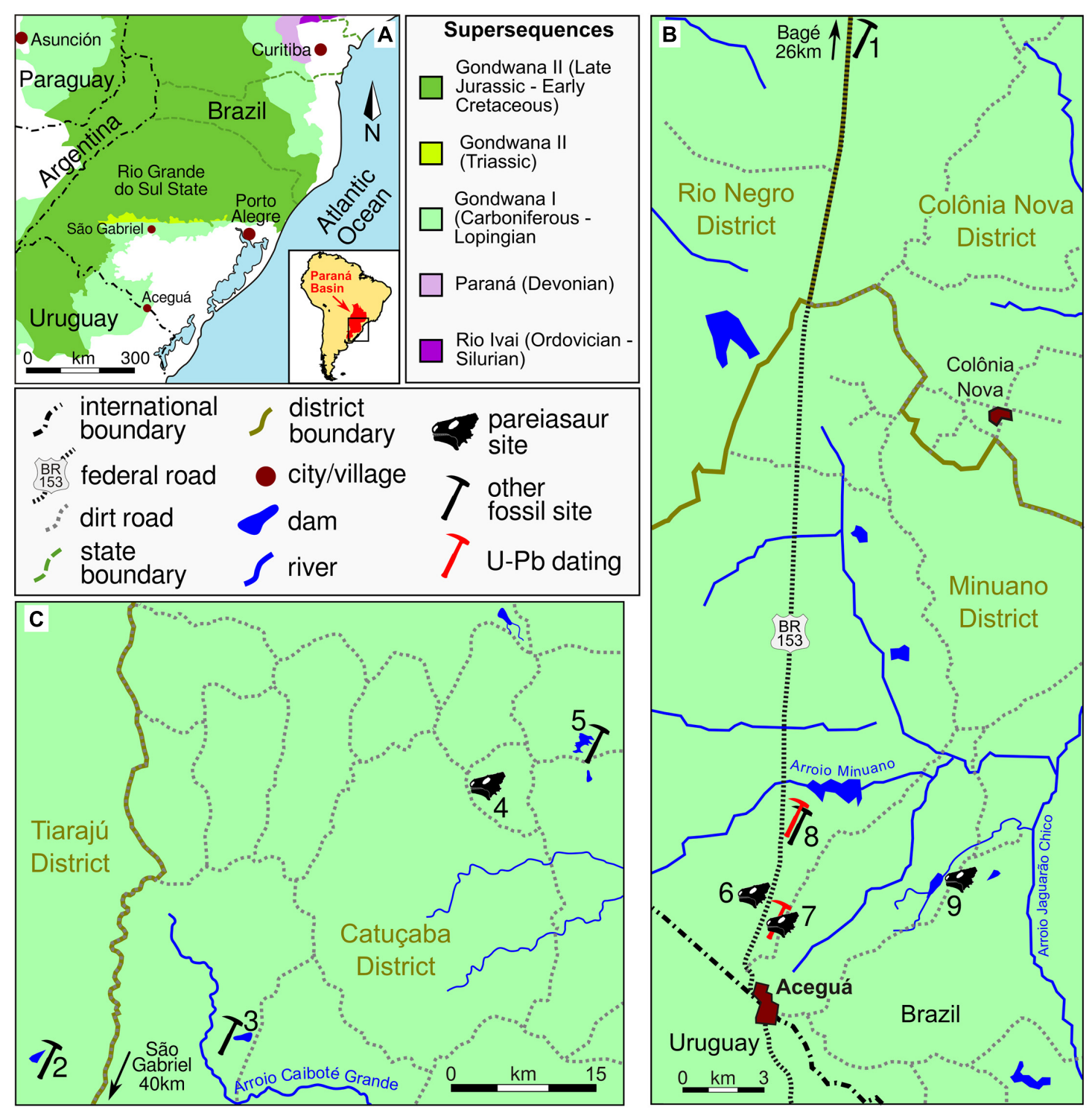

FIGURE 1 | Provenance of Rio do Rasto Formation pareiasaurs and other fossils in Rio Grande do Sul State. (A) Paraná Basin in southern Brazil. The Rio do Rasto Formation is included in the Gondwana I Supersequence. (B) Rio do Rasto sites in the Aceguá Municipality. (C) Rio do Rasto sites in the São Gabriel Municipality. (1) Coxilha Grande Farm, type locality of the temnospondyl Bageherpeton longignathus (Dias and Barberena, 2001) and the chondrichthyan Xenacanthus santosi (Würdig-Maciel, 1975); (2) Capão Alto Farm, archosauromorphs, type locality of Tiarajudens eccentricus and Triodus richterae (Cisneros et al., 2011; Martinelli et al., 2017; Pauliv et al., 2017); (3) 'Coprolândia,' coprolite-rich site (Dentzien-Dias et al., 2012); (4) Unnamed farm property of Modesto Spencer Fagundes (= 'Posto Queimado'), MCP 4263PV, dinocephalians, temnospondyls, chondrichthyans and bony fishes (Langer, 2000; Malabarba et al., 2003; Cisneros et al., 2005); (5) Boqueirão Farm, type locality of the dinocephalian Pampaphoneus biccai, the dicynodont Rastodon procurvidens, and the temnospondyl Konzhukovia sangabrielensis (Cisneros et al., 2012; Boos et al., 2016; Pacheco et al., 2017); (6) BR-153 Highway, km 665.4, west side of the road, type locality of Provelosaurus americanus, holotype UFRGS-PV-0231-P, UFRGS-PV-0232-P, *UFRGS-PV-0358-P and *UFRGS-PV-0376-P (Araújo, 1985b); (7) BR-153 Highway, km 666, east side of the road, UFRGS-PV-0233-P (Araújo, 1985b), fish remains and U-Pb dating (Rocha-Campos et al., 2019); (8) BR-153 Highway, Km 659.5, east side of the road, lungfish burrow and U-Pb dating (Francischini et al., 2018); (9) Santo Antônio Farm, *UFRGS-PV-0359-P. *New Provelosaurus americanus specimens. Supersequences follow Milani et al. (2007).

(Figure 2C). In addition to the Provelosaurus americanus remains (UFRGS-PV-0359-P), this outcrop has a unique variety of fossils that includes fish teeth and scales, spiral coprolites, plant impressions (Glossopteris communis, sphenophytes) and petrified wood.
The only pareiasaur site outside Aceguá is located $170 \mathrm{~km}$ NW, in the property of Modesto S. Fagundes (Figure 1C, site 4), in the Catuçaba District within the municipality of São Gabriel, an exposure that has been informally referred to as "Posto Queimado" in the literature (Langer, 2000). 

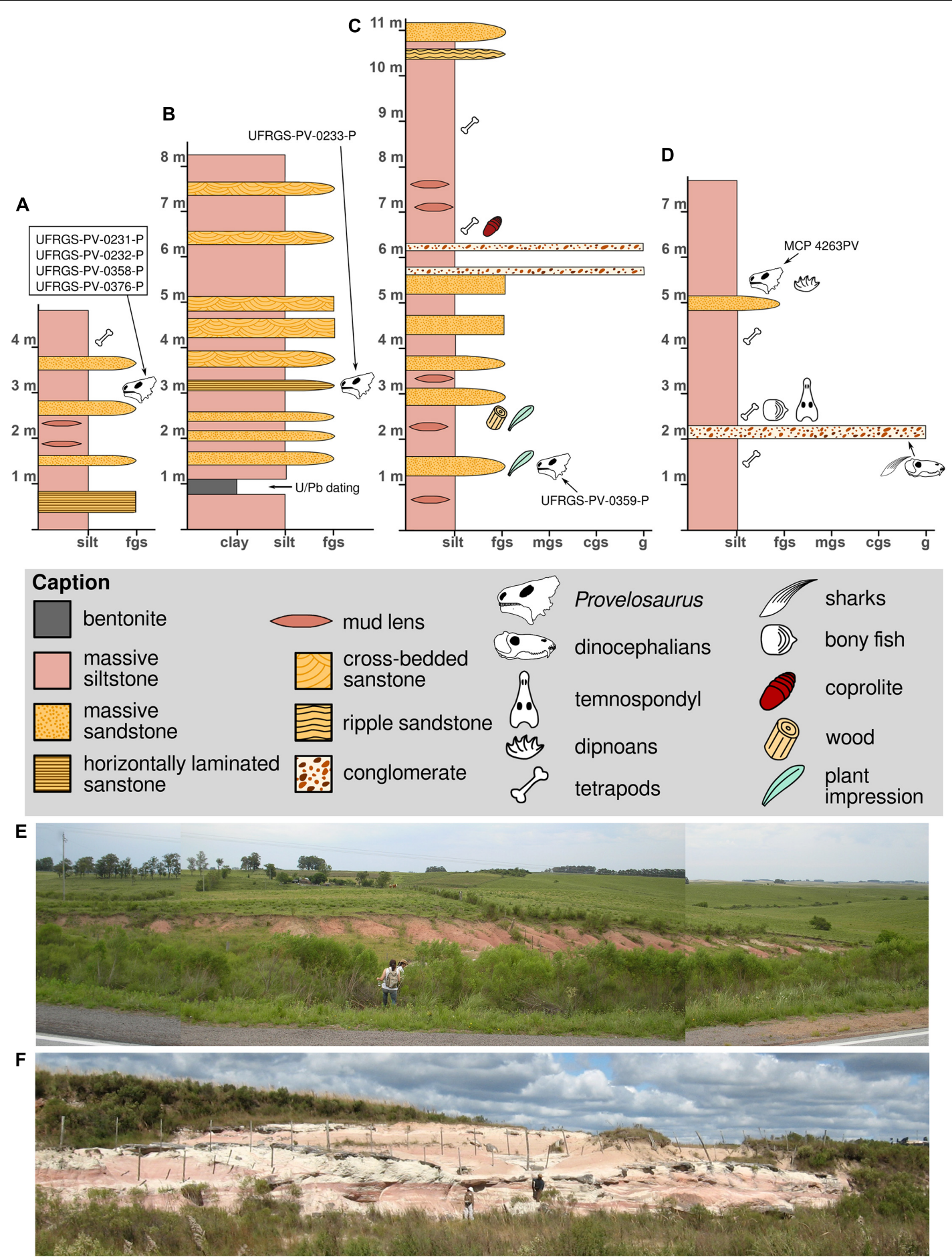

FIGURE 2 | Stratigraphic logs (A-D) and general view (E,F) of the exposures that produced pareiasaur remains, see Figure $\mathbf{1}$ for locations. (A,E) Type locality of Provelosaurus americanus, photograph taken in 2009, the locality is now largely covered by vegetation; (B,F) exposure at km 666, with a bentonite layer $U-P b$ dated 266.7 土 5.4 Ma (Rocha-Campos et al., 2019); (C) Santo Antônio Farm outcrop; (D) Fagundes site stratigraphic log.

Note that other authors incorrectly used this name for other exposures in São Gabriel, sometimes even including outcrops located at different municipal districts (e.g., DiasDa-Silva, 2012; Pacheco et al., 2017), thus making the name "Posto Queimado" largely ambiguous. This small outcrop is a sequence of massive siltstone interbedded by a conglomerate and a sandstone level that has produced a variety of vertebrate remains (Figure 2D) and the partial 
skull of a juvenile Provelosaurus americanus (MCP 4263PV) (Cisneros et al., 2005).

\section{MATERIALS AND METHODS}

The three new specimens here described were collected in the municipality of Aceguá during fieldworks in 2008. UFRGS-PV0358-P and UFRGS-PV-0376-P were found in situ at the typelocality (Figures 1, 2E), only a few meters from each other. UFRGS-PV-0359-P was discovered at the nearby Santo Antônio Farm, at the margin of the main water-dam (Figure 1). The fossil was located at the east side of the dam, ex situ and mostly disarticulated, but nearby a sandstone lense which we consider to be its host rock. This fossil has many recent fractures, presumably produced by farm machinery. In addition, we address undescribed autopodium remains located in the UFRGS-PV collection. These were already prepared and have the catalog number UFRGS-PV-0233-P, thus, being part of the original material designated by Araújo (1985b).

A phylogenetic analysis was performed based on the data matrix used by Liu and Bever (2018). Although the latest pareiasaurian data matrix was published by Van den Brandt et al. (2019), this dataset contains only cranial character scores. The present description includes abundant postcranial material, for this reason we based our cladistic analysis on the former study (character list can be found in Turner et al., 2015). Characters were edited using the software Mesquite (Maddison and Maddison, 2019) (see Supplementary Information for data matrix). The analysis was run on the software TNT (Goloboff and Catalano, 2016). Provelosaurus americanus was re-coded for 31 character states. Shihtienfenia permica was re-coded for characters 90 and 91 following (Benton, 2016) and Bradysaurus baini was modified for character 125 after (Van den Brandt et al., 2021a). Three new characters were included in the data matrix. Character (140): marginal teeth, at mid region of maxilla or jaw, dorsoventrally tall (root-apical/mesiodistal ratio $=1.5$ or higher), present $(0)$ or absent (1). Character (141): premaxillary tooth number, three (0), four or more (1), or two (2). Character (142): if the tabular (= supernumerary bone) is dorsally exposed, it does not contact the parietal (0), or it contacts the parietal (1). The polarity of character 79 was reversed (see Supplementary Information for data matrix). A "traditional search" was carried out with Wagner trees and 100 replicates, TBR algorithm, saving 100 trees per replication, using collapsing rule 1 (collapsing branches with ambiguous supports) and setting memory space for 29,999 trees. Two other searches were performed with the same parameters but excluding Obirkovia gladiator from Russia (Bulanov and Yashina, 2005) and Sanchuansaurus pygmaeus from China (Li and Liu, 2013), two taxa known from fragmentary fossils.

\section{Institutional Abbreviations}

MCP, Museu de Ciências e Tecnologia, Pontifícia Universidade Católica do Rio Grande do Sul (PUCRS), Porto Alegre, Brazil. SAM, Iziko South African Museum, Cape Town, South Africa.
UFRGS-PV, Paleovertebrate Collection, Universidade Federal do Rio Grande do Sul, Porto Alegre, Brazil.

\section{RESULTS}

\author{
SYSTEMATIC PALEONTOLOGY \\ REPTILIA Laurenti (1768) \\ PARAREPTILIA Olson (1947) \\ PAREIASAURIDAE Seeley (1888) \\ Provelosaurus Lee (1997a) \\ Provelosaurus americanus (Araújo, 1985b).
}

\section{Holotype}

UFRGS-PV-0231-P. Skull, right scapulocoracoid and humerus.

\section{Referred Material}

UFRGS-PV-0232-P, pelvic girdle of a juvenile individual; UFRGSPV-0233-P, partially articulated postcranium, including humerus, vertebrae, ribs, pelvis, femur, tibia, fibula, metapodials, phalanges, and osteoderms. Newly referred material is represented by UFRGS-PV-0358-P, a partial skull; UFRGS-PV-0359-P, partial skull, right mandible, left humerus, partial left scapulocoracoid, ribs, clavicle, one ungual phalanx, interclavicle, vertebrae and osteoderms; UFRGS-PV-0376-P, scapulocoracoid and a partial rib of a juvenile individual; MCP 4263PV, left partial cranium (more information in Supplementary Material).

\section{Locality and Horizon}

All material housed at UFRGS was found in the municipality of Aceguá, Rio Grande do Sul State, near the border of Uruguay (Figure 1B). MCP $4263 \mathrm{PV}$ was found in the municipality of São Gabriel, Rio Grande do Sul State (Figure 1C). The exposures are considered to represent the Morro Pelado Member of the Rio do Rasto Formation, Guadalupian (Langer, 2000; Cisneros et al., 2005).

\section{Amended Diagnosis}

Moderate-size pareiasaur, characterized by the following autapomorphies: (1) anterior maxillary teeth very tall and thin (apicobasal/mesiodistal ratio > 1.7) with only seven cusps; (2) prefrontal dorsoventrally expanded, forming all the anterior border of the orbit; (3) quadratojugal with a long smooth ventrolateral surface with two prominent bony spines on its posterior end; (4) squamosal dorsoventrally expanded; (5) angular boss with a triangular outline in lateral view, having an oblique anterior margin and a perpendicular posterior margin in relation to the tooth plane; (6) interclavicle with a long median stem, its length being equal to transverse dimension of lateral rami; and (7) cervical vertebrae with dorsoventrally flat, wing-like transverse processes.

\section{Comments}

We provisionally retain autapomorphy (4); however, the holotype skull is laterally flattened, which could have artificially increased the vertical dimension of the squamosal. 


\section{DESCRIPTION}

The osteology of Provelosaurus americanus has been described in detail in a series of papers (Araújo, 1985a,b, 1986a,b; AraújoBarberena, 1987, 1989a,b; Cisneros et al., 2005). Therefore, the present study will focus on the novel information provided by the new specimens and the undescribed autopodial elements from UFRGS-PV-0233-P, with a brief account and rectifications on the holotype and previously referred material when appropriate.

The type skull of Provelosaurus americanus (UFRGS-PV0231-P) likely represents the largest individual found so far having a maximum anteroposterior dimension of $330 \mathrm{~mm}$. The lateral flattening that affected the fossil, however, artificially increased this measurement. The undistorted skull probably had a maximum length of $300 \mathrm{~mm}$. Considering a snout-vent length equivalent to four heads (Broom, 1903; Lee, 1997a; Tsuji, 2013), the Provelosaurus americanus type specimen would measure approximately $1.2 \mathrm{~m}$ in this dimension, and some $0.6 \mathrm{~m}$ at the shoulder (Figure 3). A smaller snout-vent of $1 \mathrm{~m}$ is likely for the sub-adult postcranium UFRGS-PV-0233-P. With these body measurements the Brazilian pareiasaur is comparable in size to Shihtienfenia permica from China (Benton, 2016, Figure18), and slightly smaller than the Russian Deltavjatia rossicus, which has a reported snout-vent length of $1.5 \mathrm{~m}$ (Tsuji, 2013).

\section{Cranium}

The holotype of Provelosaurus americanus (UFRGS-PV-0231$\mathrm{P}$ ) includes a rather complete skull minus the palate, and parts of the basicranium, largely compressed and fractured along the sagittal plane due to diagenesis (Figure 4). It was found divided in two halves that were put together after preparation (Araújo, 1985b). The newly collected specimens, UFRGS-PV-0358-P and UFRGS-PV-0359-P (Figure 5), have skulls that show two cylindrical bosses on the quadratojugal, and are readily referable to Provelosaurus americanus. UFRGS-PV-0358-P comprises a partial skull, consisting mainly of the left lateral skull bones and most of the dorsal cranial surface minus the snout, with small portions of the basicranium and palate. Despite being relatively large, equivalent in size to the holotype, UFRGS-PV0358-P is partially disarticulated. Considering that pareiasaurs are notorious for having hyperossified skulls and that their sutures are often difficult to be traced, this specimen probably represents a young adult. The third skull, UFRGS-PV-0359-P, is badly fractured. Recognized elements include the right cheek bones and some upper marginal teeth. The cranial bones of this specimen are visibly swollen, a taphonomical artifact probably due to recrystallization of iron and/or manganese oxide. The basicranial and palatal bones of Provelosaurus americanus will be the subject of further studies to be published elsewhere.

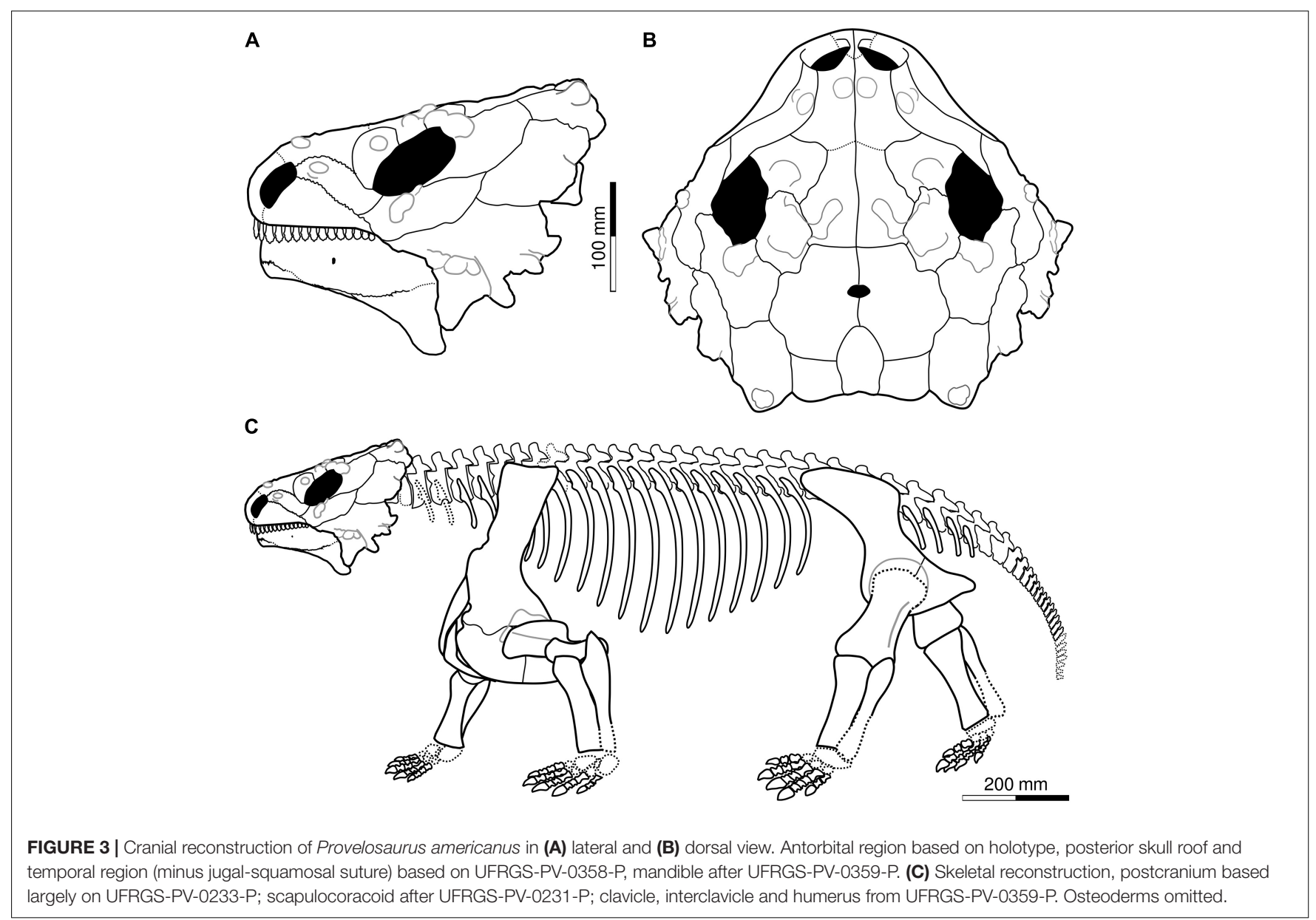




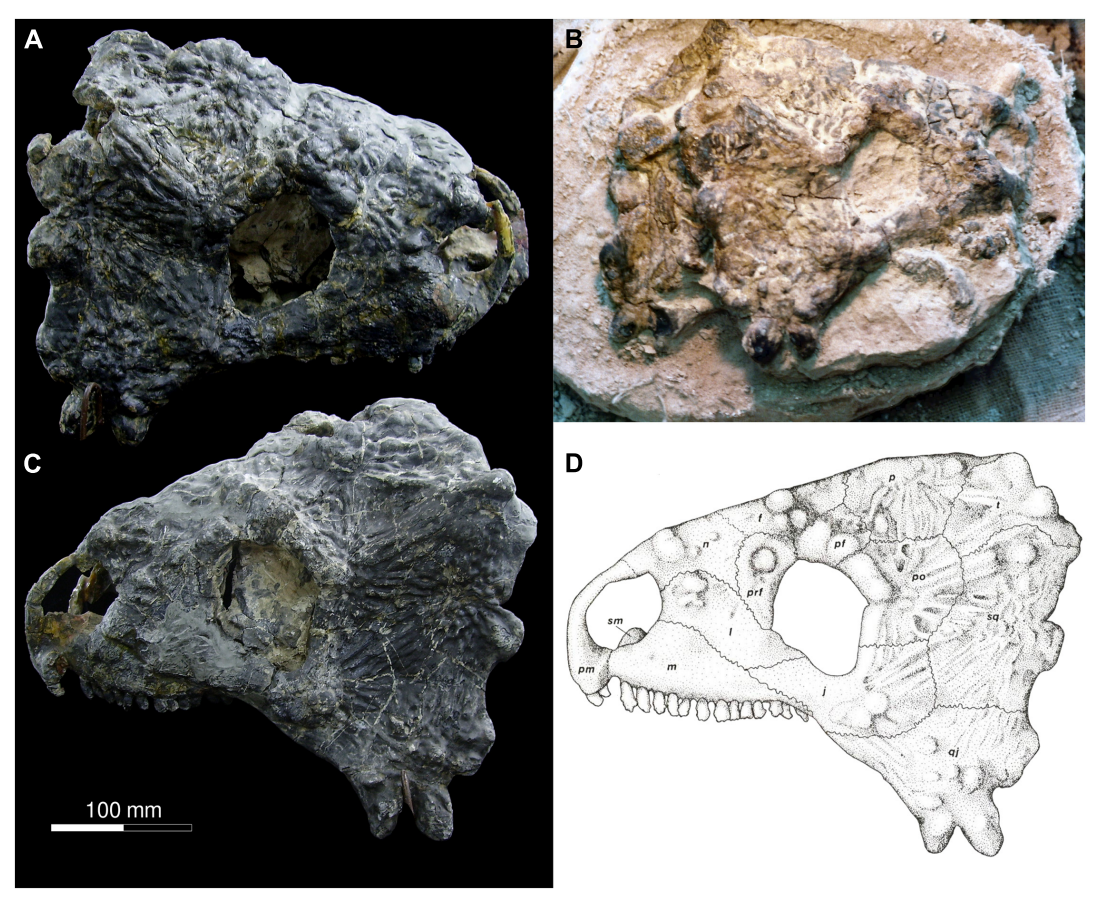

FIGURE 4 | Skull of Provelosaurus americanus, UFRGS-PV-0231-P (holotype). (A) Right lateral view; (B) field photograph showing right lateral view and partial medial view of left side of skull (photo from the UFRGS-PV collection), (C) left lateral view; (D) original drawing from Araújo (1985a). Scale bar for (A,C,D).
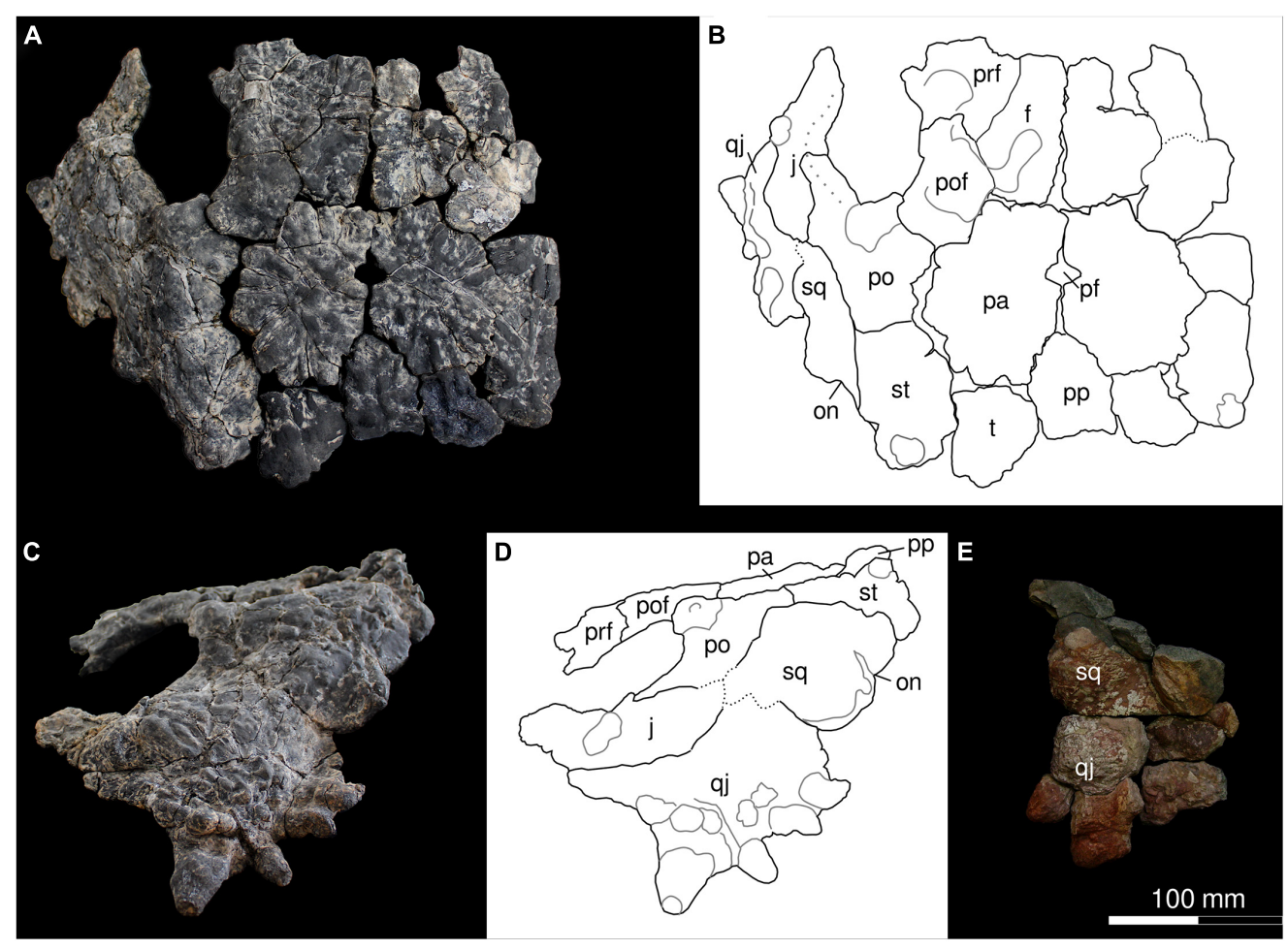

FIGURE $\mathbf{5}$ | Skulls of Provelosaurus americanus. (A-D) UFRGS-PV-0358-P, in (A,B) dorsal and (C,D) left lateral views. (E) UFRGS-PV-0359-P, portion of the temporal region in right lateral view. f, frontal; j, jugal; pa, parietal; pf, parietal foramen; po, postorbital; pp, postparietal; prf, prefrontal; pof, postfrontal; qj, quadratojugal; sq, squamosal; on, otic notch; st, supratemporal; t, tabular. Continuous gray lines represent major bosses. 
Both premaxillae were found somehow displaced in the holotypic skull. This bone lacks ornamentation and forms the ventral and anterior portions of the naris. Anteriorly it rises as an arcuate dorsal process that appears more gracile than in other pareiasaurs. The premaxilla bears only two teeth, being in this respect similar to the "dwarf pareiasaurs" and to Deltavjatia rossicus (Tsuji, 2013), but contrasting with the condition seen in most pareiasaurs where three teeth are present (Lee, 1997b). Its contacts with both the nasal and the maxilla are not clear due to damage.

The maxilla of Provelosaurus americanus has a typical parareptilian outline in lateral aspect, with a high anterior wall that thins posteriorly. It forms the posteroventral border of the external naris, shares an oblique dorsal suture with the lacrimal and the jugal, and lacks the sculpturing seen in other bones. The anterior maxillary foramen is not well preserved in the holotype but it can be seen in the juvenile skull MCP 4263PV (Cisneros et al., 2005). The maxilla is swollen anteriorly but lacks the prominent tubercle that other pareiasaurs have in this area. The maxillary dentition of Provelosaurus americanus is better preserved on the left side of the type skull, where it bears 13 teeth. The anterior marginal teeth of the Brazilian pareiasaur are unique in being conspicuously tall, mesiodistally thin, with labiolingually flattened crowns and having a low number of cusps (seven to nine). The first three teeth in the holotype have height/mesiodistal dimension ratios of 2.0, 2.0, and 1.72, respectively. Comparable tooth ratios are only seen in Chinese pareiasaurs such as Honania complicidentata and Shihtienfenia permica (the latter, based on lower dentition) (Xu et al., 2014; Benton, 2016) but these species feature a higher number of cusps (10 in Honania complicidentata, 13-17 in Shihtienfenia permica) and also a prominent cingulum that is absent in the Brazilian species. Although Araújo (1985a) reported the presence of a cingulum in the upper marginal teeth, we found no evidence of this in the holotype. This is further confirmed by maxillary teeth from the Santo Antônio Farm specimen. The upper marginal teeth from both UFGRS-PV-0358-P and the holotypic skull, however, bear lingually what can be better described as pads at the base of their crowns.

The lacrimal is elongated in lateral aspect, lying obliquely in relation to the tooth margin, contributing to the posterior border of the naris. It contacts the nasal and the prefrontal dorsally, the maxilla ventrally, and the jugal posteriorly. This bone bears anterior bosses and forms the anteroventral portion of the orbital rim. In the juvenile skull MCP 4263PV, the lacrimal appears to rise posteriorly, forming the anterodorsal margin of the orbit (Cisneros et al., 2005). This discrepancy with the holotype, however, could be due to misidentification of the suture with the prefrontal in MCP 4263PV, because some bone contacts are not clear in this specimen. If the latter is correct, it is the prefrontal that forms the anterodorsal orbital rim in MCP 4263PV and not the lacrimal.

The nasal is only present in the type specimen. Due to the flattening that the fossil suffered, it lays exposed in the lateral view of the skull. The nasal contributes to the dorsal margin of the naris anteriorly, and is bordered by the dorsal margin of the lacrimal and the anterior border of the prefrontal and the frontal posteriorly, although the suture with the later is not clear. Anteriorly, the nasal bears a prominent tubercle and posteriorly it has an emargination that interdigitates between the lacrimal and the prefrontal.

The prefrontal is known from the type skull and portions present in UFRGS-PV-0358-P, and probably also in MCP 4263PV (see above). Anteriorly, the bone contacts the lacrimal and the nasal. Its medial border is part of the roof of the skull where it borders the frontal, and posteriorly, the postfrontal. In lateral aspect, the bone appears basically as a crescent that contributes to the anterior rim of the orbit. Its main feature is a dorsal tubercle that is part of the circumorbital bumps that characterize pareiasaurs and other parareptiles (Tsuji, 2006).

The frontal is present in the holotype and in UFRGS-PV-0358$\mathrm{P}$, although it is partially fused with some neighboring bones in both specimens, and with its counterpart in the latter, making its relationships difficult to assess. The bone is subrectangular, with a moderate lateral process that intermeshes between the contact of the prefrontal and the postfrontal, but does not reach the orbit. Its dorsal surface bears thick sculpturing, which is apparently more organized in the holotype. A large tubercle surrounded by smaller bumps and radiating ridges is present in the mid portion of the bone in the type skull. In UFRGS-PV-0358-P there is also a main tubercle in the center but it is less prominent, being loosely separated from other bumps. The posterior border of the frontal contacts the parietal in a sinuous, mediolateral line that is well exposed in UFRGS-PV-0358-P.

The jugal is found in the type skull and is nearly complete in UFRGS-PV-0358-P. The new specimen confirms features described by Araújo (1985a). In lateral view, the bone is a crescent that forms the posteroventral rim of the orbit. Its contribution to the orbit is thickened and the transition from the ventral to the posterior edge is rather abrupt, a change that is also visible in dorsal view. Its anterior process is covered by subtle sculpturing, but two large circular bosses are present in the central portion of the bone, followed posteriorly by ridges that radiate from them and continue in the quadratojugal and squamosal bones. Its acute anterior end is bordered dorsally by the lacrimal and anteroventrally by an oblique sinuous suture with the maxilla. Its dorsal margin is a nearly straight horizontal interdigitating suture shared with the postorbital. Only a tiny portion of the jugal reaches the ventrolateral margin of the skull. Its posteroventral border is a convex edge limited by the quadratojugal and by a vertical contact with the squamosal.

The postorbital of UFRGS-PV-0358-P confirms the general morphology of the holotype, although its sutures are not as clear as in the type skull. The bone forms the posterodorsal edge of the orbit. Its contribution to the rim is thickened, its width being further increased at its dorsal portion by a pair of bosses. The posteriormost boss marks the edge where the roof meets the skull lateral surface, forming a distinct angle. This junction is covered by ridges that project posteriorly and extend through the supratemporal. The transition from the posterior to the dorsal margin of the orbit is somewhat abrupt. The posterior margin of the postorbital is convex and bordered by the squamosal and the supratemporal. In dorsal view, the postorbital has a short exposition. Its anterior border here is 
embayed, being the recipient of a convex posterior process of the postfrontal. Medially, it shares an anteroposteriorly oriented suture with the parietal.

The quadratojugal is well preserved in specimen UFRGS-PV0358-P and to a lesser degree also in UFRGS-PV-0376-P. The bone is bordered anteriorly by the jugal and dorsally by a large squamosal. The quadratojugal forms the posterolateral edge of the skull, being the main constituent of the lateral flanges that form the typical "helmet" of all pareiasaurs. The main feature of this bone are two large conical tuberosities with rounded apexes that protrude from the skull as bony spines, located between the junction of the ventral and posterior edges of the skull. The anteriormost spine is oriented ventrolaterally and is the largest in UFRGS-PV-0358-P (36 $\mathrm{mm}$ from the base to the tip) (Figures 5C,D). In this specimen, a second, much smaller spine ( $24 \mathrm{~mm}$ from the base to the tip) is located posteriorly. The main axis of this spine is oriented posterolaterally, and slightly ventrally as well. We note differences in the proportions of these quadratojugal spines among the available specimens. In MCP $4263 \mathrm{PV}$ the second spine is also the smallest (Cisneros et al., 2005), but in the holotype (Figure 4) and in UFRGS-PV-0376$\mathrm{P}$ the second spine is the largest of the two. These morphological discrepancies could be related to individual variation. In all four specimens, these two quadratojugal spines are the largest in the skull and the only present in the ventral edge of the lateral wings. No other pareiasaur has this arrangement of quadratojugal spines, allowing recognition of the Brazilian species based on this diagnostic feature (see discussion in Cisneros et al., 2005). The lateral surface of the quadratojugal is sculpted by circular bosses and radial ridges that continue in the jugal and, to a minor extent, in the squamosal. The posterior border of the quadratojugal bears a wide, dorsoventrally expanded boss. In the juvenile MCP 4263PV this boss is a homogeneous structure but in the holotype it is subdivided in two minor tuberosities, and in UFRGS-PV0358-P, the boss bears two small, posteriorly oriented spines. No tuberosities or spines are visible over this boss in UFRGS-PV0376-P, but the taphonomic alteration suffered by this specimen could have obliterated them.

The squamosal of Provelosaurus americanus forms a large part of the lateral surface of the posterior portion of the skull. In UFRGS-PV-0358-P this bone appears square and lower than in the holotype, where it is a subrectangular, dorsoventrally expanded bone, its maximum dorsoventral dimension being equivalent to nearly 1.5 times its anteroposterior dimension. UFRGS-PV-0358-P, however, bears many fractures in the temporal region and these sutures are tentative. The bone is bordered ventrally by a nearly horizontal contact with the quadratojugal, anteriorly it shares a sinuous contact with the jugal and the postorbital, and dorsally with the supratemporal. A ventrodorsally elongated boss protrudes from the posterior border of the bone. This structure is subrectangular in the type skull but is more rounded in UFRGS-PV-0358-P. A smaller, rounded tuberosity is present dorsally, adjacent to the contact with the supratemporal. The shape and proportions of the squamosal are distinctive in the Brazilian pareiasaur. Most pareiasaur species have squamosals in which the dorsoventral and anteroposterior dimensions are roughly equal (Boonstra, 1934a;
Lee, 1997a; Tsuji, 2013; Van den Brandt et al., 2019), giving this bone an almost square shape in lateral view, and in the genera Nochelesaurus and Pareiasuchus, the anteroposterior dimension exceeds the ventrodorsal one (Lee et al., 1997; Van den Brandt et al., 2021b). An exception is Arganaceras vacanti from Morocco (Jalil and Janvier, 2005), a pareiasaur that also features a dorsoventrally expanded squamosal albeit lacking the prominent posterior boss present in the Brazilian species. The otic notch occurs between the two mentioned bosses, at the posterior border of the squamosal. It has $12.8 \mathrm{~mm}$ in width and joins a shallow groove that runs ventrally to the region of contact between the squamosal and the paroccipital process of the exoccipital.

The parietal bone is bordered anteriorly by the frontal and the postfrontal, laterally by the postorbital and the supratemporal, posteriorly by the small tabular, and posteromedially by the single postparietal. The parietal is basically a triradiate structure, having an anteroposterior dimension equivalent to 1.5 times its mediolateral length. Its ornamentation is clearly radial, with a central boss from which various ridges emanate. As in most pareiasaurs, the pineal opening is located in the anterior portion of the bone. Its shape, however, is very distinctive. Whereas in most pareiasaurs the pineal foramen is anterodorsally elongated, either oval, teardrop-shaped, or roughly circular, in Provelosaurus americanus this structure appears anteroposteriorly compressed, having a lateral dimension that represents nearly double the anteroposterior dimension.

The supratemporal is present in the holotype and in UFRGSPV-0358-P. This bone is fused with the tabular in the type skull but in UFRGS-PV-0358-P a suture is present and these bones are disarticulated. Following early authors (e.g., Boonstra, 1934a) who identified the bone at the posterior corner of the skull roof as a tabular (Araújo, 1985a) regarded the two fused bones to represent a tabular as well. In dorsal view, the supratemporal of Provelosaurus americanus is basically a hexagonal plate with convex anterior and posterior margins. The bone forms the lateral edge of the skull and is bordered anterolaterally by the postorbital, anteromedially by parietal, and medially by the tabular. In contrast to other pareiasaurs, the supratemporal does not contact the postparietal. The supratemporal is sculptured by ridges and bears a prominent tubercle near the posterior margin. The bone is less exposed in lateral aspect, showing a short anterior contact with the postorbital and a ventral concave margin bordered by the squamosal.

The tabular in pareiasaurs has been traditionally regarded as a "supernumerary bone" (e.g., Lee, 1997b; Jalil and Janvier, 2005). Following Tsuji (2006), we consider this bone to be a true tabular. The right tabular is nearly fused to the parietal in UFRGSPV-0358-P, but the left tabular is disarticulated. In dorsal view, this bone exhibits an almost trapezoid outline, being remarkably similar to the tabular of Pumilliopareia pricei (Broom and Robinson, 1948). This bone contacts the parietal, excluding the supratemporal from reaching the postparietal. This is in contrast to most pareiasaurs but the condition occurs in Pareiasuchus nasicornis (Lee, 1997a) and the dwarf pareiasaurs Pumilliopareia pricei and Anthodon serrarius (Boonstra, 1934a; Broom and Robinson, 1948; Lee, 1997a). The tabular contacts the postparietal medially, and the supratemporal laterally. Its posterior border is 
slightly convex. Its surface is sculptured by longitudinal ridges, with bosses located near the posterior margin.

The postparietal was found disarticulated in UFRGS-PV0358-P and is better preserved than in the holotype. The bone is larger than the tabular and it has a pentagonal outline in dorsal view, being in this respect similar to Deltavjatia rossicus. Its anterior borders protrude as a wedge within both parietals, its lateral margins are nearly parallel, and its posterior border is slightly concave. Its surface has ornamentation in the form of irregular bosses.

\section{Mandible}

The Santo Antônio Farm specimen, UFRGS-PV-0376-P, provides the first Provelosaurus americanus mandible (Figure 6). It is divided in two main fragments that connect to each other, together comprising most of the right hemimandible, minus most of the adductor fossa and some portions of the dentary and the splenial. Due to lithostatic compression, the anterior portion of the ramus has been folded inwards at a $90^{\circ}$ angle, giving the mandible an "L" outline in occlusal view. The dentary forms a large portion of the ramus, covering most of the labial view, extending from the symphysis to the level of the angular boss, gradually becoming higher posteriorly. It is unclear if this is a natural feature or a taphonomical artifact due to compression on the ramus. A well developed foramen dentofaciale majus is visible below the 10th tooth. The dentary is limited ventrally by the splenial and posteroventrally by the angular. The posterior contact with the surangular is either damaged or not preserved. Sixteen tooth positions are recognized, although it is uncertain if a few additional teeth could be present in the missing fragments of the dentary. This number, however, is consistent with the 15 upper marginal tooth positions found in the holotypic skull (Araújo, 1985a). All the mandibular teeth have lost their crowns and little can be said regarding their morphology except that they are thecodont, subcircular in basal cross section and have relatively long cervices. At least four resorption pits at various stages of development are recognized in the hemimandible, being located from the 8 th to the 11 th preserved tooth positions.

The splenial complements the dentary in the anterior half of the ramus, forming most of the lingual and ventral margins in this region, and having a small labial exposure below the first four teeth. The lingual view of the area adjacent to the symphysis is damaged and the relationships of the splenial and the dentary cannot be assessed here. Posteriorly, the splenial shares an oblique contact with the prearticular and apparently with the coronoid, and posteroventrally with the angular. A large, oval foramen intermandibularis caudalis is located at the confluence of the splenial, angular, and prearticular bones.

The angular covers all the posteroventral margin of the mandibular ramus. In lateral view, this bone shares a long, mostly horizontal, dorsal contact with the dentary, and posteriorly, a small contact with the articular. Its relationship with the surangular, however, is obscured due to damage in the latter. The main feature of the angular is a well developed boss. It has a triangular outline in lateral view, with a slightly concave anterior surface that is at roughly $35^{\circ}$ in relation to the tooth plane, and a posterior surface that is nearly perpendicular to the tooth margin. The boss ends distally as a slightly curved, posteriorly pointed apex. In posterior view, the angular boss appears as a vertical projection from the jaw, showing no inclination to either medial or lateral facet. Most pareiasaurs possess cylindrical angular bosses with a main axis that is perpendicular to the tooth row in lateral view. Other pareiasaurs such as Embrithosaurus schwarzi and Nochelesaurus alexanderi (Van den Brandt et al., $2019,2021 b)$, show some degree of posterior inclination of the angular boss but this condition is limited to the apex, being mostly cylindrical in lateral view, rather than triangular as in the Brazilian taxon. Furthermore, the bosses of these Karoo species are curved medially, a condition that contrasts with Provelosaurus americanus. The angular boss in Pareiasuchus nasicornis is somewhat triangular in labial view and similar to that of Provelosaurus americanus, but differs in being strongly inclined medially (Haughton and Boonstra, 1930a: plate 36). Pareiasuchus peringueyi shows an angular boss that is strongly directed posteriorly, however, the morphology of this structure differs from the Brazilian taxon in being a knob with a globular, blunt end (Haughton and Boonstra, 1930a, Figures 9, 10). The wide base of the angular boss of the Brazilian taxon is comparable to that present in the Russian Scutosaurus, however in the latter both anterior and posterior surfaces of the boss are oriented at a comparable angle, resulting in a conical boss with a axis that appears vertical both lateral and posterior views. In addition, the angular boss of Provelosaurus americanus is located more posteriorly than in most pareiasaurs. Thus, the morphology of the angular boss of this species is unique among pareiasaurs and is here regarded as a diagnostic character of the Brazilian taxon.

As previously mentioned, the surangular is badly damaged, its contacts with the surrounding bones cannot be confidently traced and the adductor fossa is largely missing. The coronoid is also damaged, missing its dorsal process, and being currently exposed only in lingual view. A fragment of displaced bone that covers part of the dentary below the 12th and 13th teeth is probably a portion of the coronoid.

The articular is relatively well preserved although its sutures with the adjacent bones are not clear in lateral view. In medial view, however, this bone is largely exposed overlaying portions of the angular and the prearticular. The large surface of this bone in this view is reminiscent of Embrithosaurus schwarzi (e.g., Van den Brandt et al., 2019). Two transversally oriented, oval condyles for articulation with the quadrate are preserved, the anteriormost being much larger than the posterior one, and being separated from it by a shallow glenoid fossa. The posterodorsal end of the articular is marked by the presence of a curved retroarticular process, which tapers dorsally and does not form a lump as in other pareiasaurs.

\section{Postcranium \\ Axial Skeleton}

The vertebral series of Provelosaurus americanus was described in detail by Araújo-Barberena (1989b) on the basis of the nearly complete column minus cervicals from specimen UFRGSPV-0233-P. She reported 13 dorsal vertebrae, but based on articulated rib fragments she estimated that the two anteriormost 


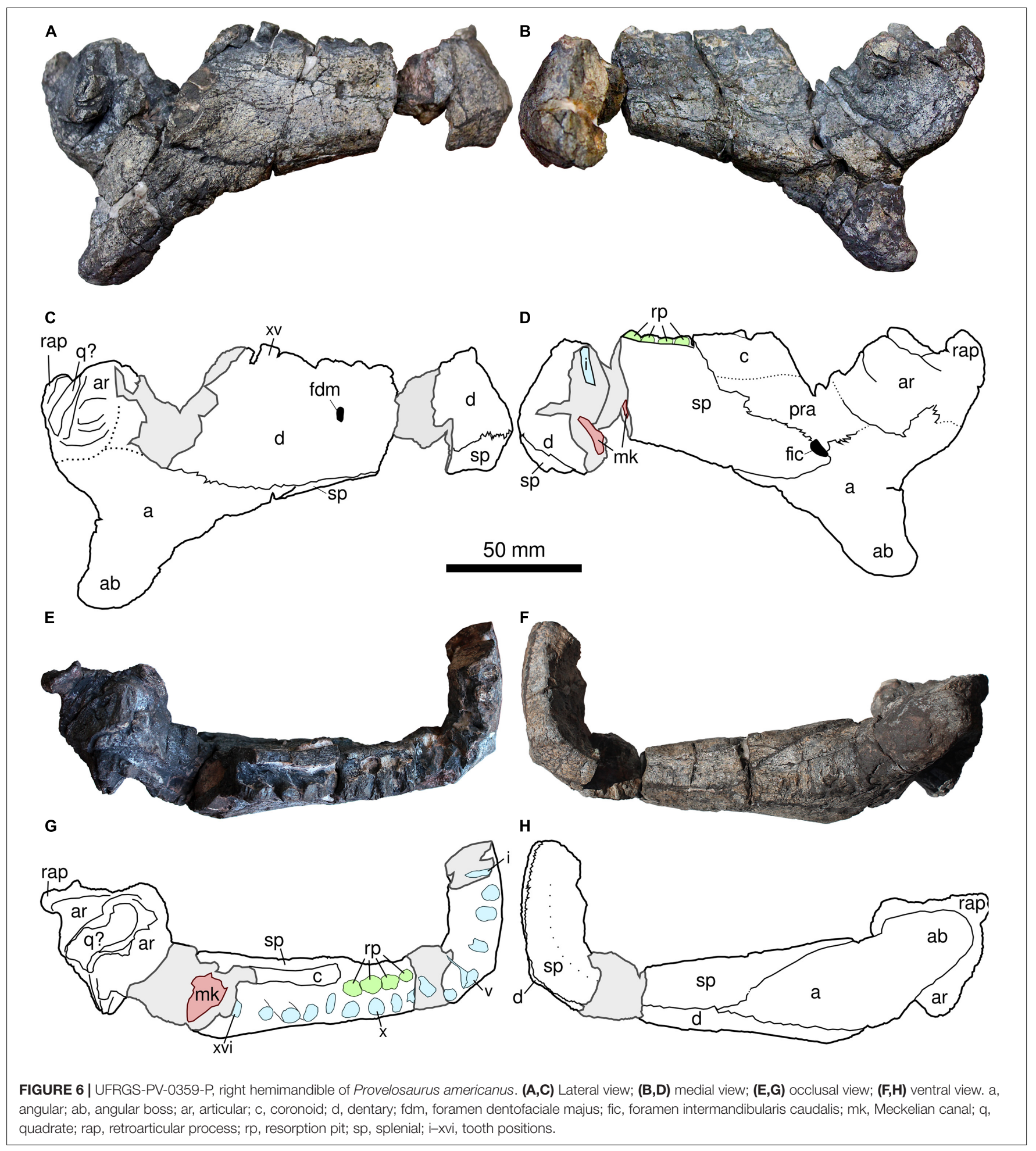

vertebrae were missing, suggesting a total number of 15 dorsals, in addition to four sacrals and an indeterminate number of caudals. Five cervicals and one anterior dorsal vertebra are preserved in the new specimen from the Santo Antônio Farm, UFRGS-PV-0359-P (Figure 7), allowing to complement the original description.
As in all pareiasaurs, the vertebrae of Provelosaurus americanus are amphicoelic and show characteristic swollen neural arches that are transversely expanded. As far as it can be corroborated, all vertebrae are notochordal. A pair of attached vertebrae are tentatively identified here as the atlas-axis complex (Figures 7A-F). The very damaged atlas is basically a small, 


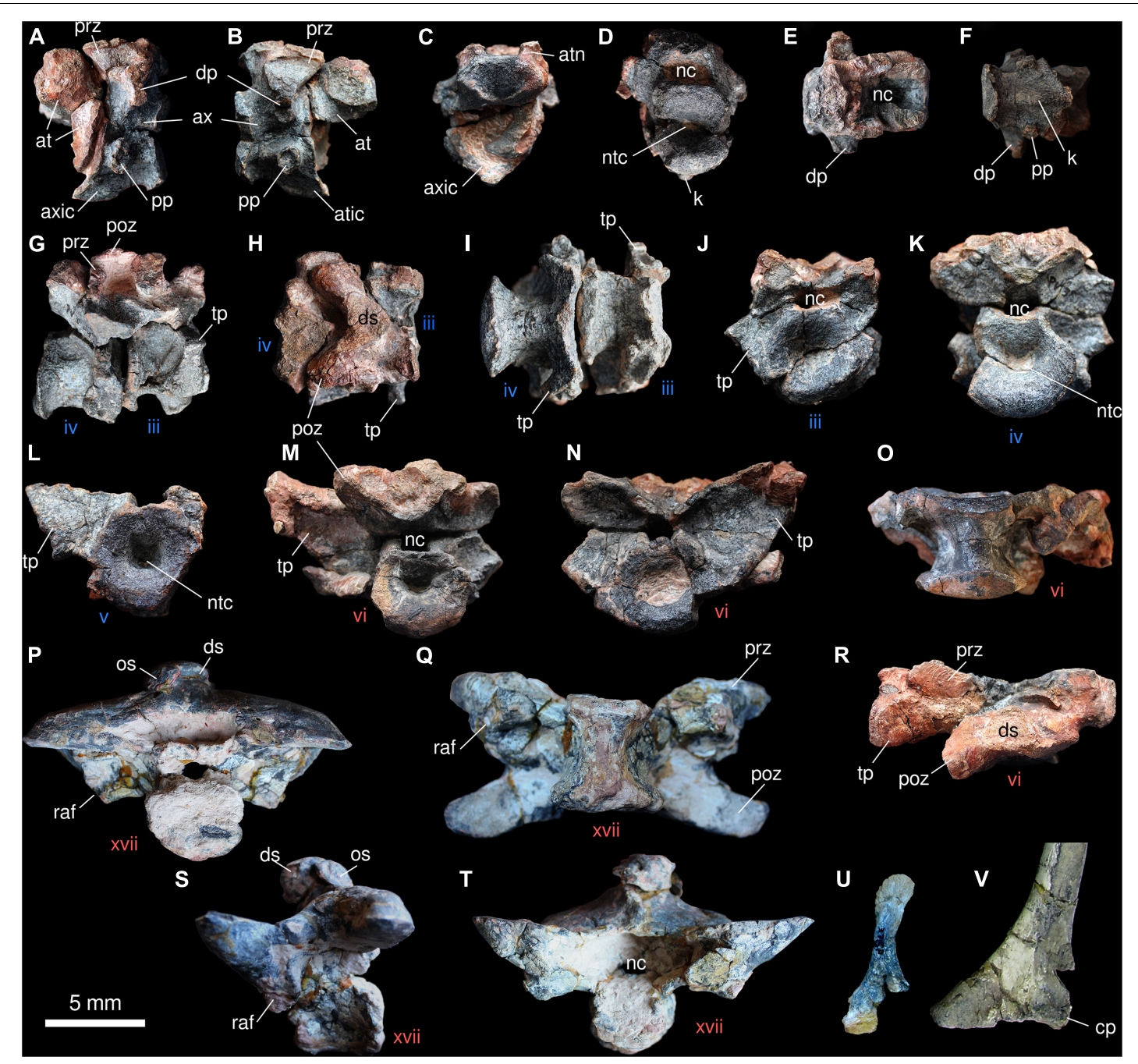

FIGURE 7 | Anterior axial skeleton of Provelosaurus americanus. (A-N,O,R) UFRGS-PV-0359-P; (P,Q,S,T,V) UFRGS-PV-0233-P. (U) UFRGS-PV-0376-P. Atlas and axis in (A) left lateral, (B) right lateral, (C) anterior, (D) posterior, (E) dorsal, and (F) ventral views. Third and fourth cervical vertebrae in (G) right lateral, (H) dorsal, (I) ventral, (J) anterior, and (K) posterior views. (L) Cervical vertebra in anterior view. First dorsal vertebra in (M) posterior, (N) anterior, (O) ventral, and (R) dorsal views. Posterior dorsal vertebra in (P) posterior, (Q) ventral, (S) left lateral and (T) anterior views. (U) Cervical rib, ?anterior view. (V) Right dorsal rib head in anterior view. at, atlas; atic, atlas intercentrum; atn, atlas neural arch; ax, axis; axic, axis intercentrum; cp, capitulum; dp, diapophysis; ds, dorsal spine; k, keel; nc, neural canal; ntc, notochordal canal; os, osteoderm; pp, parapophysis; poz, postzygapophysis; prz, prezygapophysis; raf, rib articular facet; tp, transverse process, iii-xvii, vertebrae numbers (blue, cervicals; red, dorsals).

moderately concave centrum with neural arches. There is no trace of a proatlas or an atlas intercentrum, but these could have been lost. The axis has lost its dorsal spine. This vertebra has a very concave anterior surface that, together with a fused intercentrum, encases a large portion of the atlas. Short, anterodorsally oriented prezygapophyses are visible. Ventrally, these fuse with the bases of a transversally, directed, diapophyses. The left diapophysis is better preserved than the right one, its articulation for the rib being in the form of a vertical ellipse with a slightly concave anterior surface. Parapophyses are also preserved, being smaller than the diapophyses, and mostly cylindrical, with a circular articular facet. As mentioned above, the axis intercentrum is fused with the pleurocentrum. It extends anteriorly providing support for the ventral surface of the atlas. On its ventral surface it features a prominent sagittal keel, a structure that represents the ventralmost point of the atlas-axis complex.

The posterior cervicals (3rd, 4th, and 5th) are peculiar in that they do not have distinct diapophyses and parapophyses, contrasting with the condition described in other pareiasaur species, where these processes are separated (Boonstra, 1934c; Benton, 2016; Van den Brandt et al., 2021a). In the vertebra identified as the third cervical, the fused parapophysisdiapophysis forms a transverse process that has the shape of a minute triangular wing, with a lateroventrally oriented dorsal surface and a laterodorsal facet for articulation with a holocephalous rib (Figures 7I,J). This structure is well preserved on the left side of that vertebra. In the following cervicals (4th and 5th), this transverse wing progressively expands laterally 
and slightly dorsally, and its distal margin folds posteriorly. The latter feature can be well seen in ventral view. The neural arches are better preserved in the third cervical, although the prezygapophyses and the dorsal spine are damaged. The pair of postzygapophyses, together with the base of the dorsal spine, form a chevron in dorsal view, and the maximum lateral extent of each zygapophysis does not surpass that of the wing formed by the fused diapophysis-parapophysis. The pleurocentra are strongly convex in the three posterior cervicals and their ventral surfaces are also slightly pinched laterally, having an hourglass shape in ventral aspect. No intercentra were found associated with the posterior cervicals, and the shape and space between each pleurocentrum leaves little room for them. As previously mentioned, the presence of a transverse process in the cervicals appears to be unique to Provelosaurus americanus and is here tentatively regarded as a diagnostic feature of the taxon. There are, however, few comprehensive descriptions of the cervical series within Pareiasauria, our knowledge of this region basically being represented by the forms from the Tapinocephalus Assemblage Zone (Van den Brandt et al., 2021a) and the Chinese Shihtienfenia permica (Benton, 2016). Cervical ribs has been located, in the juvenile specimen UFRGS-PV-0376-P (Figure 7U) and in UFRGS-PV-0359€-P. It is basically a short rod with an expanded, anterodorsally flat head that is not fully preserved, and a spatulate, rugose end.

One vertebra from the Santo Antônio Farm specimen displays a morphology that is somehow intermediate between the fifth cervical and the dorsals, and is here considered to represent the sixth presacral vertebrae and the first from the dorsal series (Figures $\mathbf{7 M - O , R}$ ). This dorsal vertebra features a transverse process that is laterally wider than that present in the cervicals, dorsally surpassing the articular facet of the prezygapophysis. The latter, in turn, is transversally larger than in the cervicals. The postzygapophyses are not fully preserved but these are clearly wider than in the recognized cervicals. There is still some morphological gap between this vertebra and the dorsals present in the articulated column from UFRGS-PV-0233-P. In the latter, the anterior dorsals feature prezygapophyses with a transverse dimension that surpasses that of the transverse process. For this reason, we estimate that one anterior dorsal vertebra (the second dorsal one) is missing in both specimens. Thus, the combined series represented by the five cervicals and first dorsal found in UFRGS-PV-0359-P, plus a putative second dorsal missing, and the 13 dorsals present in UFRGS-PV-0233-P would result in a total of 20 presacrals for Provelosaurus americanus. Based on UFRGS-PV-0233-P, the following dorsals (tentatively, presacrals 8th to 20th) (Figures 7, 8) show a trend of lateral expansion of both prezygapophyses and postzygapophyses that reaches its peak in the last four presacrals. This results in posterior dorsals transversally wider than the anterior ones (9th presacral transverse dimension $=158 \mathrm{~mm}$; 17 th presacral transverse dimension $=192 \mathrm{~mm}$ ). The transverse process, on the other hand, merges with the prezygapophysis in the dorsal vertebrae, and progressively reduces its vertical dimension, becoming a mere facet for articulation of the rib that protrudes lateroventrally from the base of the prezygapophysis. The dorsal pleurocentra appear less concave than the cervical ones and small dorsal intercentra are present. Minute, likely non-functional, hypantra and hyposphenes are found above the neural canals (AraújoBarberena, 1989b). The dorsal spines are short, robust and slightly inclined anteriorly, a factor that, in combination with the prominent lateral expansion of the zygapophyses, creates very low posterior dorsal vertebrae (Figures $\mathbf{7 P , S}, \mathbf{T}, \mathbf{8 A}$ ). This results in a geometry that contrasts with the condition in other pareiasaur species, where the dorsal vertebrae feature a dorsoventral dimension that is greater than or subequal to the transverse dimension. In the posterior dorsal vertebrae of Provelosaurus americanus, the transverse dimension is equivalent to $\sim 1.6$ times the dorsoventral dimension. Although the vertical compression suffered by the fossil could be partially responsible for the vertebrae being overly low, their spines are too short to be considered exclusively the result of a taphonomic feature. Ribs are present along the complete dorsal portion of the column. None of them is fully preserved in its extension. They are conservative, featureless, ventrally recurved rods. They are basically holocephalous, with triangular heads, but an incipient tubercle can be recognized in the posterior dorsal ones (Figure 7V).

The sacral series found in UFRGS-PV-0233-P comprises four vertebrae (Figure 8). Their pleurocentra are robust but dorsoventrally lower than the dorsals, and bear distally expanded ribs for articulation with the iliac blade. The first sacral vertebra is the largest of the group, featuring massive ribs that are posterolaterally oriented, and considerably wider in anteroposterior dimension than the following. The dorsal spine and the prezygapophyses of the first sacral vertebra show the same morphology and dimensions of the preceding dorsal vertebrae. The dorsal surfaces of the second, third and fourth sacrals are not well preserved, and are partially covered with osteoderms, precluding detailed observations, but their zygapophyses appear less developed than in the first one. In the second and the third sacrals, the axis of the ribs is nearly perpendicular in relation to the sagittal plane. In the fourth sacral, this rib also departs perpendicularly from the pleurocentrum but distally it curves anteriorly. This rib is less expanded distally than in the three anterior sacrals. No intercentra were found among the sacrals, but the space present between the pleurocentra suggests that these could have been lost.

The anterior portion of the caudal region is preserved in UFRGS-PV-0233-P (Figure 8), likely comprising at least half of the tail. The first four caudal vertebrae bear ribs and can be individually recognized, although their dorsal surface is damaged and their dorsal spines are broken. These vertebrae bear reduced zygapophyses and small, proximally thickened ribs. Their ventral surface is not prepared. The remaining caudal vertebrae are smaller, simplified versions of the anterior ones, apparently lacking ribs. They are too badly preserved to be individually recognized, but some ten vertebrae can be estimated, resulting in approximately 14 caudals preserved in UFRGS-PV-0233-P. A few additional, smaller vertebrae should have been present to complement the caudal series. The poor preservation of these vertebrae precludes observation of facets for hemal arches or the presence of intercentra. 


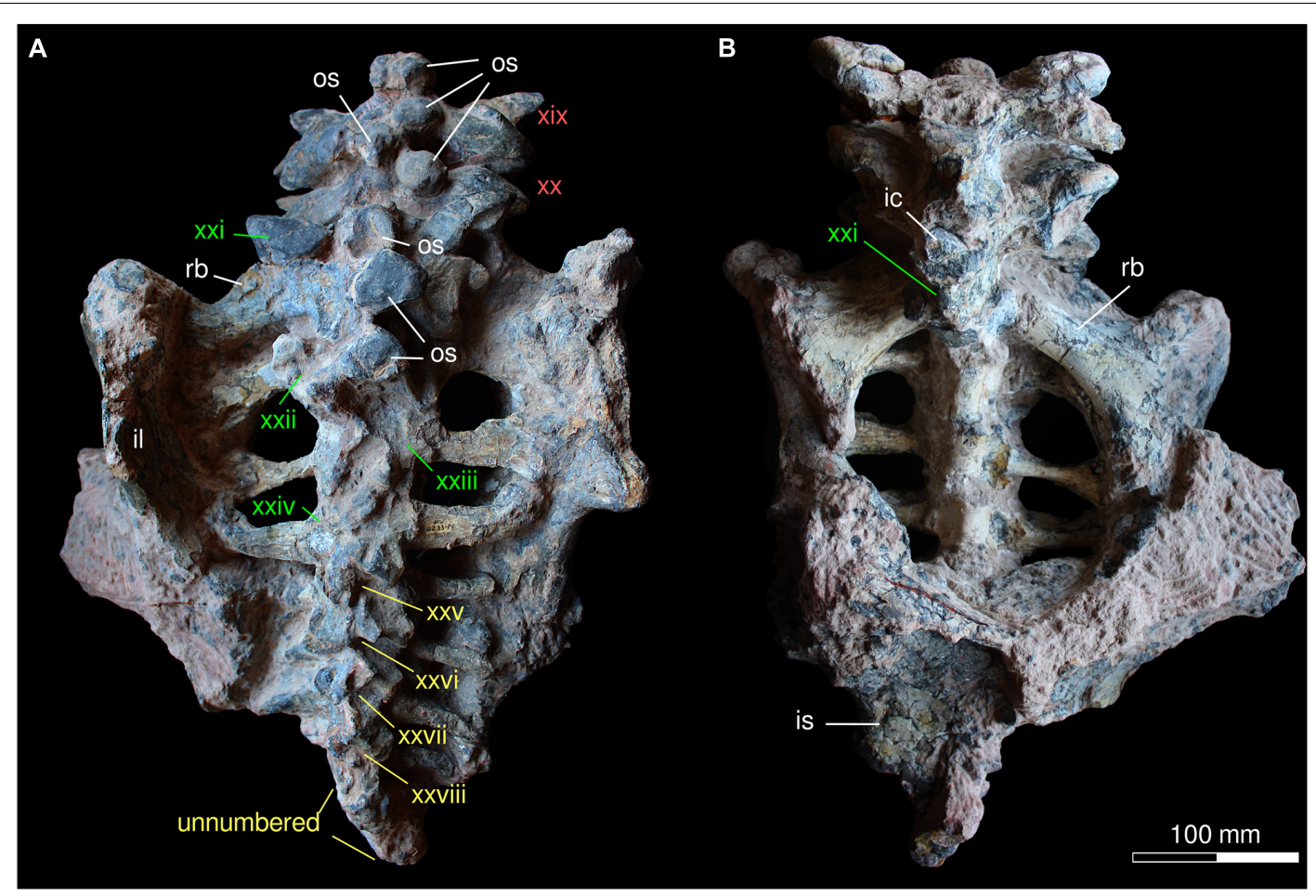

FIGURE 8 | Posterior axial skeleton of Provelosaurus americanus, UFRGS-PV-0233-P, in (A) dorsal and (B) ventral views. ic, intercentrum; il, ilium; is, ischium; os, osteoderm; rb, rib; xix-Xxviii, vertebrae numbers (red, dorsals; green, sacrals; yellow, caudals).

\section{Shoulder Girdle}

The Santo Antônio Farm specimen (UFRGS-PV-0359-P) provides the first Provelosaurus americanus interclavicle (Figures 9A-D). It has the typical anchor shape that is characteristic of pareiasaurs and procolophonoids, basically formed by a transverse bar that is perpendicular to a posterior, longitudinal rod. The transverse bar is formed by two laterally projected arms that have acute ends and are dorsally bowed. In anterior view, each arm has a deep, arcuate, rugose sulcus for articulation of the clavicles. This groove thins progressively toward the midline, meeting its counterpart at a narrow junction where the clavicles likely had a small contact. The intersection between the transverse and the longitudinal rod is the thickest point of the bone. From here, a median stem projects posteriorly, bearing a ventral sagittal buttress that is very prominent anteriorly and weakens posteriorly. The median rod progressively flattens and decreases in thickness toward the posterior end. This stem is conspicuously long, being equivalent in anteroposterior dimension to the total transverse dimension of the lateral arms. These proportions contrast with the reported condition in other pareiasaurs, where the median rod is always shorter than the combined transverse dimension of the lateral arms (e.g., Tsuji, 2013; Xu et al., 2014; Benton, 2016; Van den Brandt et al., 2021a). The morphology of this bone in Provelosaurus americanus is, in fact, somewhat intermediate between the condition present in pareiasaurs and procolophonids (e.g., deBraga, 2003; Cisneros, 2008; Hamley et al., 2021). Therefore, the configuration of the interclavicle is considered here a diagnostic feature of the Brazilian pareiasaur. The median rod is noticeably curved posteriorly, its end being spatulate and covered with rugosities on both its ventral and dorsal surfaces. In the ventral surface these are loosely arranged as six sinuous, parasagittal rows, whereas over the dorsal surface the rugosities are mostly limited to the edges of the bone, being thicker at the posterior margin.

The first clavicles of Provelosaurus americanus are preserved in UFRGS-PV-0359-P (Figures 9G-I,P,Q). These are represented by an almost complete right bone missing the medialmost tip, and a small medial portion of the left counterpart. Combined, they provide a nearly complete view of the clavicle in this species. The clavicle is basically an arched rod that can be divided in a medial portion that articulates with the interclavicle and a lateral portion that curves dorsally. The medial portion is dorsoventrally wider and is reinforced by a thick buttress along its ventral edge. On its anterior surface it bears a mediolaterally directed, shallow sulcus. The dorsal edge of this area is damaged in both clavicles. This sulcus is not as deep as in Embrithosaurus schwarzi and Nochelesaurus alexanderi (e.g., Van den Brandt et al., 2021a). On its posterior surface there is a prominent, mesiolaterally directed keel that fits into the articular facet of the interclavicle. The ventral buttress continues onto the lateral portion of the clavicle. In anterior view, a second buttress departs obliquely from the ventral point where the clavicle is more arcuate and reaches the dorsal edge of the bone, becoming the anterior edge of the spatulate end of the clavicle. This end is a subrectangular platform that is perpendicularly oriented 


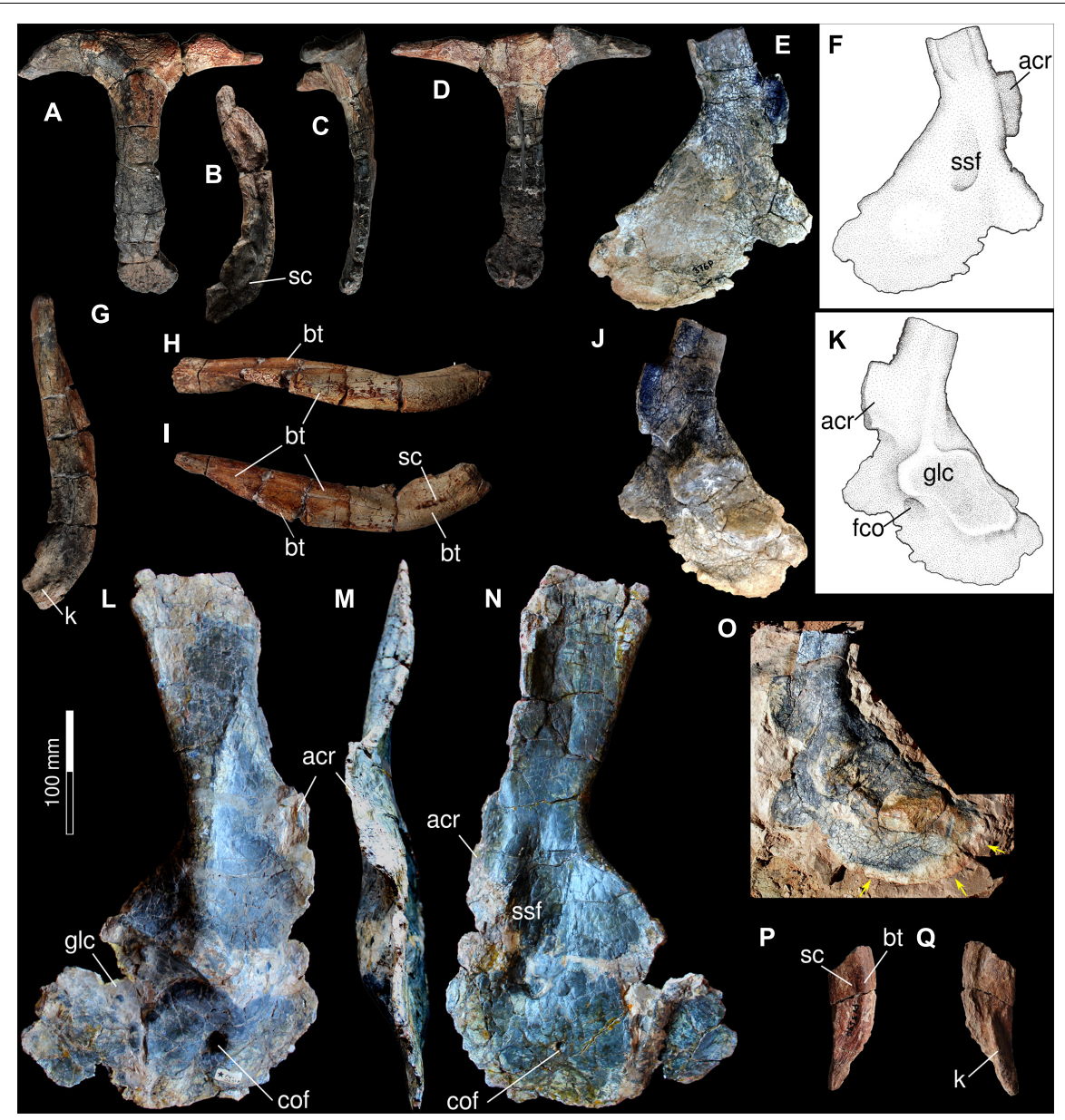

FIGURE 9 | Pectoral girdle of Provelosaurus americanus. UFRGS-PV-0359-P, interclavicle in (A) ventral view, (B) anterior view, (C) right lateral view, (D) dorsal view. (E,F) UFRGS-PV-0376-P, left scapulocoracoid in lateral view. UFRGS-PV-0359-P, right clavicle in (G) posterior (dorsal end to the top of the page), (H) lateral and (I) anterior views. (J,K) UFRGS-PV-0376-P, left scapulocoracoid in medial view. (L-N) UFRGS-PV-0231-P (holotype), right scapulocoracoid in (L) lateral, (M) anterior, and (N) medial view. (O) UFRGS-PV-0376-P, left scapulocoracoid in lateral view, field photograph showing partially ossified margin if posterior coracoid.

UFRGS-PV-0359-P, left clavicle medial portion in (P) anterior and (Q) posterior (internal) view. acr, acromion; bt, buttress; cof, coracoid foramen; glc, glenoid cavity; k, keel; sc, sulcus; ssf, subscapular fossa.

in relation to the clavicular ventral edge. It bears several thin rugosities on its ventral surface but is smooth in the dorsal aspect. In posterior view, the lateral portion of the clavicle is mostly devoid of features, except for the posterior margin of the spatulate end that smoothly merges with the main plane of the bone and some rugosities that are likely related to ligaments for attachment with the anterior coracoid or the scapula. Lateral portion bears a prominent ridge or buttress. The distal end of the clavicle is spatulate and rugose, which is similar to the condition in Embrithosaurus schwarzi and Shihtienfenia permica, but different to that in Nochelesaurus alexanderi and Bradysaurus seeleyi (Benton, 2016; Van den Brandt et al., 2021a).

The holotype of Provelosaurus americanus possesses a complete, well preserved right scapulocoracoid (Figures 9LN), which was described in detail by Araújo (1986a). The new specimen UFRGS-PV-0376-P consists of an isolated left scapulocoracoid (Figures 9E,F,J,K,O) and a cervical rib (see above), found at the Provelosaurus type locality, that belongs to an immature individual. It is very well preserved, apparently with little or no diagenetic deformation, although its sutures are not clear. The ossification of the ventral margin of the posterior coracoid is partially unfinished in UFRGS-PV-0376-P, indicating that it was cartilaginous in life. An impression of its original contour was preserved in the siltstone matrix that contains the bone. During the preparation work it was attempted to fully preserve this feature, however, it suffered some damage in the process. Its full contour can be seen in photographs taken in the field (Figure 90).

In lateral view, the dorsal portion of the scapula of Provelosaurus americanus is an anteroposteriorly oriented, mostly rectangular blade, with a nearly straight horizontal dorsal margin and a subtle concave posterior border. This blade is mediolaterally thin and in the holotype, appears sigmoidal close to the top, in cross section. This is due to a thin vertical buttress, on the medial surface, along the anterior border, and another vertical ridge that runs on the lateral surface along the 
posterior margin. These bars are also seen in the scapulocoracoid of the juvenile UFRGS-PV-0376-P, albeit the posterior one is more developed on the medial surface than on the lateral one. The acromion process is better preserved in the juvenile specimen UFRGS-PV-0376-P, where it protrudes anteriorly as a subrectangular process with a convex edge. The scapula expands anteroposteriorly toward the junction with the coracoids. In this area, in lateral view, there is a wide, dorsoventral buttress that meets the anterior dorsal border of the glenoid cavity, dorsal to the anterior coracoid foramen. It is at this point that the rim of the glenoid fossa reaches its widest lateral dimension. This buttress is faced medially by a prominent subscapular fossa that continues briefly into the anterior coracoid.

The scapula and the posterior coracoid form most of the glenoid cavity. In lateral view, the morphology of this fossa is somewhat shaped as an inverted "L," with a larger, oblique subrectangular portion on the coracoid and a smaller quadrangular portion anteriorly projected over the scapula above the anterior coracoid foramen. In this way, the outline of the glenoid fossa resembles that of Nochelesaurus alexanderi (Van den Brandt et al., 2021b). As previously mentioned, the glenoid cavity is bordered dorsally by a ridge that appears low in the holotype, probably due to compression, but is higher in UFRGS-PV-0359-P. The dorsal facet of the glenoid cavity faces laterally and slightly ventrally, contrasting with the condition in Bunostegos akokaensis from Niger, in which this facet is very ventral and supports a more verticalized humerus (Turner et al., 2015).

In the type specimen, both the anterior border of the anterior coracoid and posterior border of the posterior coracoid are damaged. In the new juvenile specimen these bones form a lamina that is anteroposteriorly larger than reconstructed by Araújo (1986a, p. 1). UFRGS-PV-0376-P shows an anterior coracoid extending anteriorly in relation to the acromion process and a posterior coracoid margin projected well beyond the margin of the glenoid cavity. A wide embayment is present along the ventral anteroventral margin of the anterior coracoid and a small part of the posterior coracoid in UFRGS-PV-0376-P, and is likely ontogenetic in nature.

\section{Forelimb}

The forelimb (Figure 10) is here described assuming a sprawling position, with the humerus main axis horizontally placed and its intercondylar fossa facing dorsally, the radius and ulna vertically oriented, with the latter being lateral to the former. Two humeri of Provelosaurus americanus have been previously described, a right one from the type specimen (UFRGS-PV0231-P) (Figures 10H-J) and another right bone from the postcranium UFRGS-PV-0233-P (Araújo, 1986b; Figures 10KM). A new right humerus (Figures 10A-G) is preserved in the specimen from the Santo Antônio Farm, UFRGS-PV-0359-P. It is of intermediate size between the two previous specimens, broken at the shaft, and showing some damage on the epicondylar flanges. Otherwise, it is better preserved than the previous fossils in some aspects, particularly its proximal and distal articulations, allowing some clarifications. Its estimated length along the main axis of the bone is $267 \mathrm{~mm}$ and its distal maximum expansion is $\sim 115 \mathrm{~mm}$ wide. Its proximal head is a wide plate (maximum expansion $\sim 150 \mathrm{~mm}$ ) with a nearly quadrangular outline in dorsal (extensor) view. In this aspect, the humerus shows a well developed oblique ridge that divides this area of the head in two surfaces, a smaller anterior (preaxial) almost triangular area and a larger (postaxial) subsquare area. The anterior surface of this ridge is mostly devoid of features and supports the deltopectoral crest. The posterior area is covered with some rugosities and a shallow buttress ("turret" in Van den Brandt et al., 2021a) that departs some $50^{\circ}$ from the main ridge and provides accommodation for the triceps muscle (Jalil and Janvier, 2005). Posteriorly, this area bears a tubercle that is bordered proximally by a notch, both features are also seen in Nochelesaurus alexanderi (Van den Brandt et al., 2021a). The ventral (flexor) surface is notoriously concave, with the deltopectoral crest forming its anterior border. As in many pareiasaurs, the proximal surface of the humerus has a wide, concave, rugose facet, indicating that a large cartilaginous cap was present for articulation with the glenoid cavity (Turner et al., 2015; Van den Brandt et al., 2021a). A notable feature reported in the humerus of Provelosaurus americanus type-material is the very low angle between its proximal and distal heads due to a strong torsion of the proximal and distal ends (Araújo, 1986b), with an angle equal or lower than $15^{\circ}$, a feature only seen among pareiasaurs in Anthodon serrarius (Boonstra, 1932; Lee, 1997a). Unfortunately, due to the fracture of the shaft, we cannot confirm this characteristic in UFRGSPV-0359-P. The entepicondyle of Provelosaurus americanus lacks the flange that is present in other pareiasaurs, and in this respect it is similar to that of the genus Pareiasuchus (Lee, 1997a). Both epicondyles project distally from the epicondylar surface in a moderate fashion, comparable to the condition in Embrithosaurus schwarzi. The entepicondylar foramen is not visible in the new fossil, but this area has some patches of matrix and this structure could be still obscured by oxide. The capitulum is a massive hemispherical structure, dominating the ventral intercondylar surface, with an oblique projection toward the end of the ectepicondyle, similar to Embrithosaurus schwarzi, barely reaching the distal end of the bone. A ridge caps the distal end of the radial condyle. It continues distally, with a small posterior bifurcation, and reaches the dorsal surface of the bone where it continues obliquely into the intercondylar fossa. The trochlear notch is moderately shallow, and is limited posteriorly by a ridge that continues onto the distal end of the head. The epicondylar distal projections do not surpass the radial and ulnar articulation surfaces.

The radius and the ulna of Provelosaurus americanus are known from the right forelimb of specimen UFRGS-PV-0233-P (Araújo, 1986b). These bones were recently cut at their shafts for histological study (Farias et al., 2021). The radius of Provelosaurus americanus (Figures 10N-P) has a conservative morphology, being mainly cylindrical with expanded, unfinished epiphyses that presumably were cartilaginous (Araújo, 1986b). The articular facet of the proximal head has a reniform outline and is somewhat convex rather than concave as it would be expected for its articulation with the capitulum of the humerus, suggesting that a large portion of cartilage was present in life. Considering the small size of UFRGS-PV-0233-P in relation to the holotype, as 

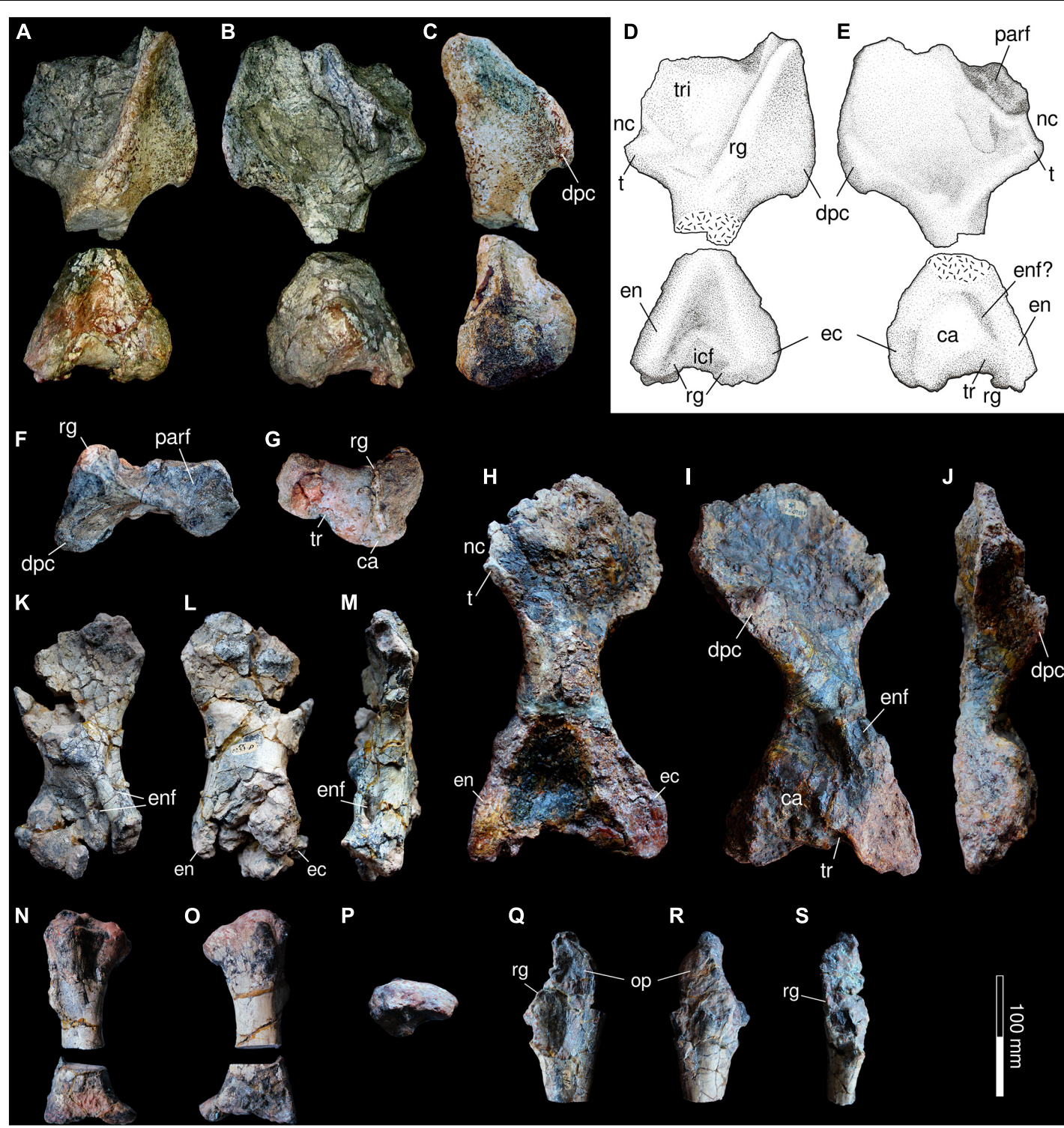

$\mathbf{P}$
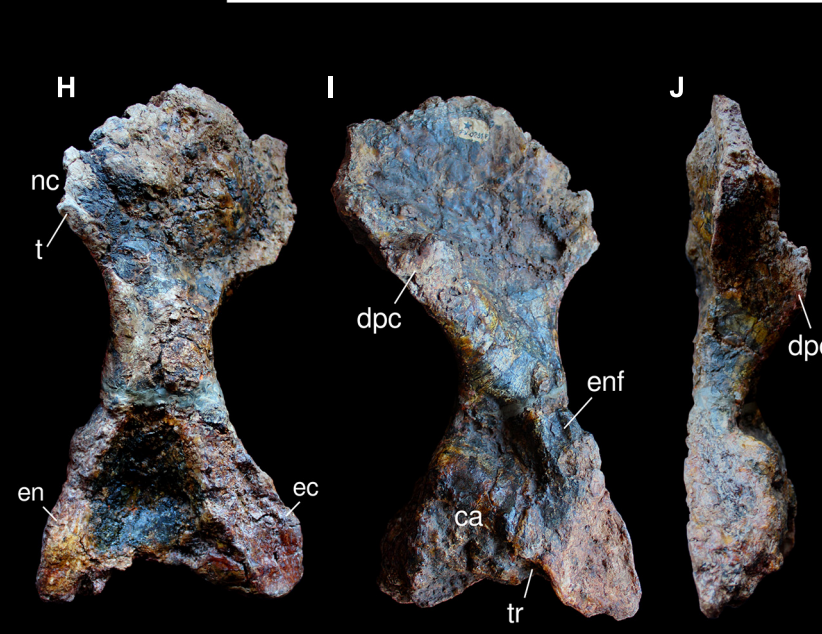

Q

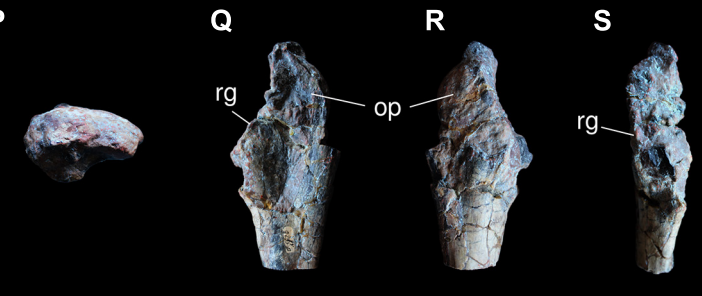

$\mathbf{S}$

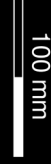

FIGURE 10 | Forelimb of Provelosaurus americanus. (A-G) UFRGS-PV-0359-P, right humerus in (A,D) dorsal (extensor), (B,E) ventral (flexor), (C) anterior, (F) proximal (dorsal to the top) and (G) distal (dorsal to the top) views. (H-J) UFRGS-PV-0231-P (holotype), right humerus in (H) dorsal (extensor), (I) ventral (flexor) and (J) anterior views. (K-M) UFRGS-PV-0233-P, right humerus in (K) dorsal (extensor), (L) flexor (flexor), and (M) anterior views. (N-P) UFRGS-PV-0233-P, right radius in (N) medial, (O) lateral, and (P) proximal views. (Q-S) UFRGS-PV-0233-P, right partial ulna in (Q) medial, (R) lateral, and (S) adductor view. ca, capitulum; dpc, deltopectoral crest; ec, ectepicondyle; en, entepicondyle; enf, entepicondylar foramen; icf, intercondylar facet; op, olecranon process; parf, proximal articular surface; nc, notch; rg, ridge; t, tubercle; tr, trochlea; tri, facet for attachment of triceps.

can be inferred comparing their humeri, this is likely a feature resulting from the immaturity of the individual at the time of death. In lateral view, the radius has a posterior concave outline facing the ulna and is notable for having a very wide distal head that is also vertically thin (Araújo, 1986b). Although the latter trait differs from most pareiasaurs (Van den Brandt et al., 2021a), in which the distal head is more robust, this may also be an artifact related to the early ontogenetic age of the individual.

Most of the right ulna was found in UFRGS-PV-0233-P (Figures 10Q-S), except for the missing distal end. The bone has several fractures and is slightly compressed in the mediolateral direction. Its proximal head appears gracile in comparison with the ulna of the large pareiasaurs from the Tapinocephalus Assemblage Zone (Van den Brandt et al., 2021a) although part of its thin constitution could be related to the compression that affected UFRGS-PV-0233-P. This bone features a moderately developed olecranon process, although its posterior extension cannot be fully assessed because its border is not completely preserved. Its facet for articulation with the trochlea is a wide, recurved notch that is bordered medially and laterally by two low ridges. Other pareiasaurs feature well developed ridges here 
and a prominent sulcus between them, but these traits are weakly developed in UFRGS-PV-0233-P.

\section{Pelvic Girdle}

Two pelvic girdles are known, both described by AraújoBarberena (1989a). The first one is part of the articulated postcranium UFRGS-PV-0233-P (Figures 8, 11E), and a second pelvis, UFRGS-PV-0232-P (Figures 11A-D), found isolated at the type locality. Both belong to immature individuals but UFRGS-PV-0232-P is smaller and more gracile. Both suffered distortion, especially the latter, which is compressed anteroposteriorly. Sutures cannot be confidently traced on any of the specimens. The ventral view is not fully prepared in UFRGSPV-0232-P and in UFRGS-PV-0233-P much of the ischium and the ventral surface of the symphysis are covered with epoxy. Due to the fragility of the former, the acetabulum was left unprepared on both sides.

In lateral view, the ilium of Provelosaurus americanus is a bone with an hour-glass outline. Its shaft shows anterior inclination, a feature more clearly seen in UFRGS-PV-0233-P, being in this respect different from the ilium of species such as Bradysaurus baini or Embrithosaurus schwarzi (e.g., Van den Brandt et al., 2021a). The iliac blade is only moderately expanded anteriorly. Its dorsal border is slightly convex and its posterior process is reduced. The acetabulum is slightly deep as far as can be seen, and is bordered dorsally by a well developed buttress. The blade is mediolaterally flattened, and in dorsal view it appears anterolaterally aligned, showing almost no eversion. The pelvic symphysis is anteroposteriorly short and the ischiatic plate is more developed than the pubic one. The posterior border of the ischium is convex, and in lateral aspect it appears posteroventrally recurved.

\section{Hindlimb}

These bones (Figure 11) are known exclusively from the right hindlimb of UFRGS-PV-0233-P, found articulated and described by Araújo (1986b). All three bones were posteriorly disarticulated in the laboratory and further prepared, and the tibia and the

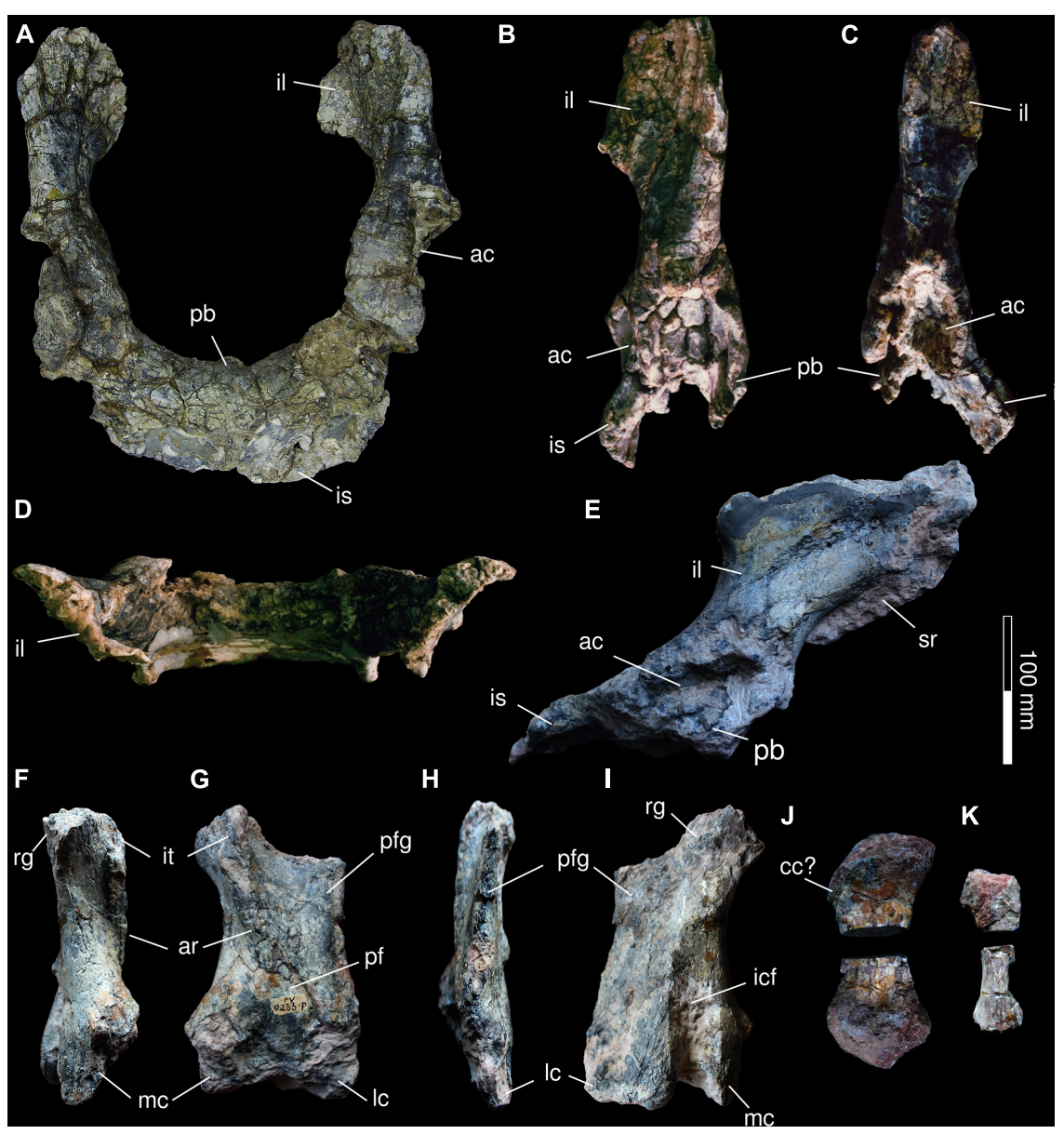

FIGURE 11 | Pelvis and hind limb of Provelosaurus americanus. (A-D) UFRGS-PV-0232-P, pelvis in (A) anterior, (B) right lateral, (C) left lateral, and (D) dorsal view (anterior to the top). (E) UFRGS-PV-0233-P, pelvis in right lateral view. (F-I) Right femur in (F) anterior (preaxial), (G) ventral (flexor), (H) posterior (preaxial), and (I) dorsal (extensor) views. (J) Right tibia in medial (flexor) view. (K) Right fibula in medial (flexor) view. ac, acetabulum; ar, abductor ridge; cc, cnemial crest; icf, intercondylar fossa; il, ilium; is, ischium; it, internal trochanter; lc, lateral condyle; mc, medial condyle; pb, pubis; pf, popliteal fossa; pfg, postaxial flange; rg, ridge; sr, first sacral rib. 
fibula were cut at their shafts for histological study by Farias et al. (2021). The femur was originally found very damaged with the proximal head missing, and the distal head incomplete. As is the case with other long bones in this sub-adult individual, large portions of the epiphyses were likely formed by cartilage, which hindered its full preservation. The femur of Provelosaurus americanus appears to have an anteroposteriorly wide shaft, in contrast to pareiasaurs such as Pareiasuchus peringueyi and Scutosaurus karpinskii (e.g., Lee, 1997a, p. 14), but is reminiscent of older forms such as Bradysaurus baini and Nochelesaurus alexanderi (e.g., Van den Brandt et al., 2021a). This is due to a well developed postaxial flange that extends distally and has a straight posterior margin, rather than a concave one as is the case in Pareiasuchus peringueyi and Scutosaurus karpinskii. In dorsal view, on its proximal region, a portion of a prominent ridge borders the anterior margin of the postaxial flange (Araújo, 1986b), a feature for muscle attachment that is shared with other pareiasaurs (Haughton and Boonstra, 1930b; Van den Brandt et al., 2021a). The intercondylar fossa is seen in this view. Araújo (1986b) noticed that this structure appears longer and deeper than expected, probably due to damage. However, in Bradysaurus baini this fossa also takes the form of a well developed sulcus (Van den Brandt et al., 2021a). In ventral view, the internal trochanter is visible on top of the abductor ridge. As in Bradysaurus baini and Embrithosaurus schwarzi (Haughton and Boonstra, 1930b; Van den Brandt et al., 2021a), this trochanter has a sigmoid outline. The abductor ridge is oriented toward the popliteal fossa and becomes shallow as it approaches it. This fossa is mostly a tear-drop shaped depression. Its distal border is damaged. As mentioned above, both distal condyles are poorly preserved.

Due to bad preservation, few details can be assessed regarding the tibia and the fibula. The former was very compressed during diagenesis and its epiphyses are not fully preserved, presumably formed by most part of cartilage in life. We can only confirm that it was a robust long bone with expanded epiphyses. The fibula, in turn, is missing more than half of its body. It is a delicate bone, almost half the width of the tibia.

\section{Autopodia}

We located 30 undescribed, partially prepared and semiarticulated autopodial elements associated with the specimen UFRGS-PV-0233-P (Figure 12). There is no information regarding the collection or preparation of this material in the UFRGS-PV laboratory notebooks, but all the bones are labeled and numbered, and the size, morphology and preservational aspect of these corroborate that they can be ascribed to Provelosaurus americanus.

Among the fossils, only metapodial and acropodial elements were recognized and their size and morphology does not allow a precise determination of their topology. All of them bear a high number of nutritional foramina, its density increasing distally. Among the metapodials, there are eight elements indicating that more than one autopodium is represented. One of the metapodials was sectioned for histological analysis by Farias et al. (2021). As in Bradysaurus seeleyi (SAM-PK-8941) and Nochelesaurus alexanderi (SAM-PK-5012) (Boonstra, 1929a,b), the metapodials of Provelosaurus americanus are longer than wider, with expanded articulation surfaces and constricted shafts, except for the element identified as the first manual metacarpal. The latter is wider than longer, pentagonal and more flattened than the other metapodials. Proximally, it has two articulation surfaces separated by a dorso-palmar-oriented constriction. The distal articulation surface of this metacarpal is elliptical and two phalanges are still articulated: the basal phalanx I and the ungual phalanx I. The remaining metapodials described here are very similar in morphology, except by their robustness and the subtriangular to elliptical shape of proximal articulation surfaces. We tentatively identify them as indeterminate II-V metapodials, possibly representing metacarpals. If our interpretation is correct, these putative metacarpals are more slender than those seen in Embrithosaurus schwarzi (SAM-PK-8944) (Boonstra, 1932) and Pareiasaurus serridens (SAM-PK-K10036).

Besides the manual digit mentioned above, three others are completely articulated, being formed by two nearly discoidal phalanges and one large, pointed ungual (suggesting that they represent either the manual or pedal digits II-IV). In these materials, the medial (or penultimate) phalanges are pulleyshaped, evincing a high range of flexion movement of the terminal and subterminal joints. However, a dorsal, proximally directed crest on the medial phalanges could restrict the dorsal extension movements on the medial-proximal phalangeal joints. Seven additional, isolated and smaller non-ungual phalanges also occur in UFRGS-PV-0233-P, evincing the shape and size of their joint surfaces. The proximal articulation surfaces are wider and taller than the distal ones.

The six ungual phalanges are dorsoventrally flattened and have a subcircular to triangular shape in dorsal view. The longer unguals are also stouter, more ventrally curved and even more acute in their distal end. The proximal articulation surface is elliptical and concave. The ventral surface of the unguals bears a keel and is separated from the dorsal one by a sharp margin and present larger foramina. A single, isolated ungual phalanx is present in UFRGS-PV-0359-P, with similar shape and size to those from UFRGS-PV-0233-P.

\section{Dermal Armor}

The osteoderms in the Brazilian pareiasaur were previously known based on specimen UFRGS-PV-0233-P (AraújoBarberena, 1987). In that postcranium, scutes were found attached to the dorsal surface of the thoracic and caudal vertebrae (Figures 7P,S, 8A), forming a narrow band over the midline of the body, as in the Tapinocephalus Assemblage Zone pareiasaurs (Boonstra, 1934b; Van den Brandt et al., 2021a) and in the Russian Deltavjatia rossicus (Tsuji, 2013). New osteoderms found in UFRGS-PV-359-P provide additional information. These were not attached to the vertebrae but instead found between the inner side of the scapulocoracoid and two cervical ribs (Figure 13A). These osteoderms are of various dimensions and show a very simplified morphology. The smallest one is circular $(11 \times 10 \mathrm{~mm})$ and the two larger ones are oval $(35 \times 23 \mathrm{~mm}$ and $26 \times 17 \mathrm{~mm})$ whereas a fourth one is partially covered by a rib. They are basically domed, lacking a central boss, the larger ones having very weak ridges. Araújo-Barberena (1987) described two main types of osteoderms over the vertebrae of 


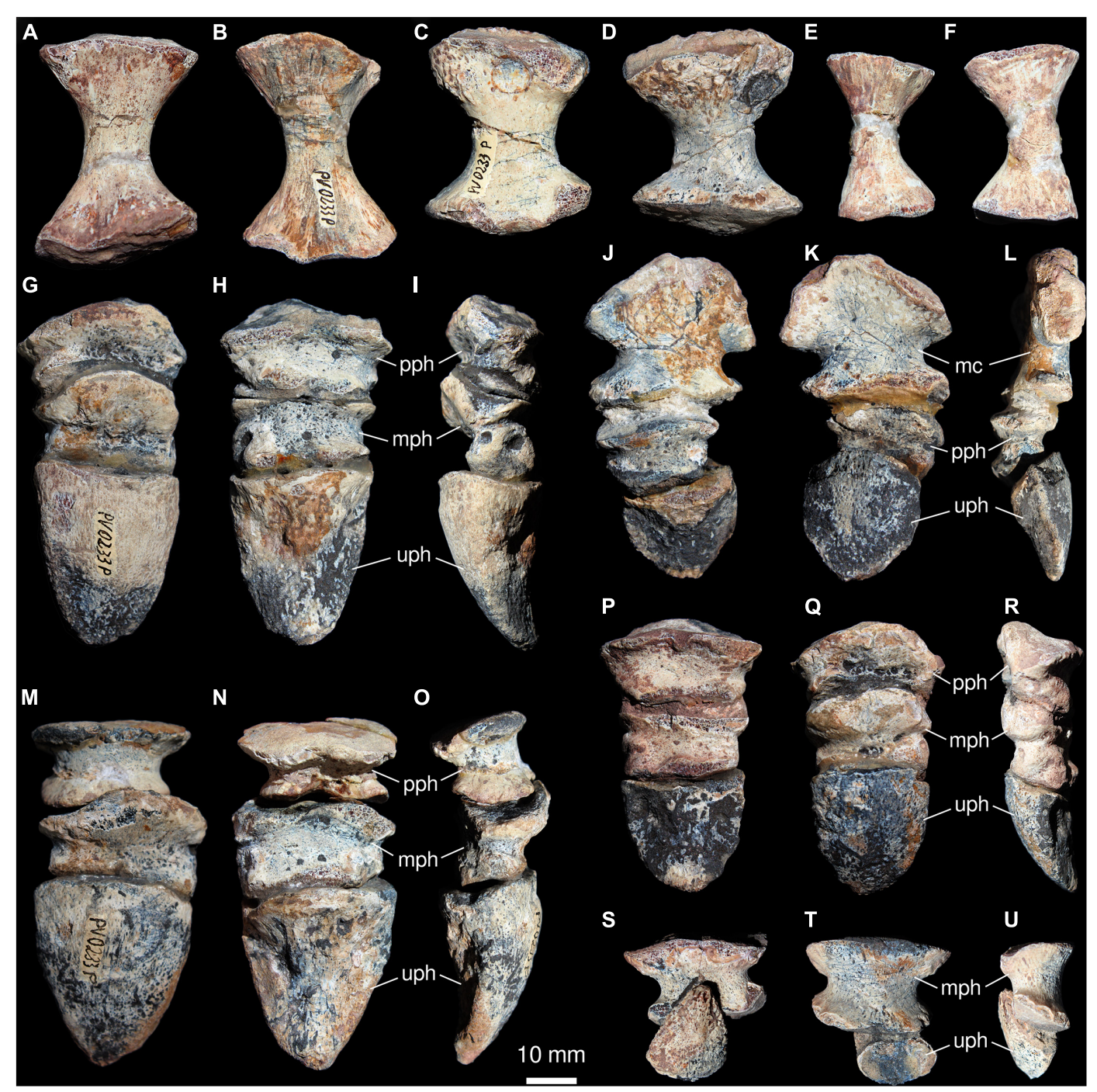

FIGURE 12 | Autopodial elements of Provelosaurus americanus (UFRGS-PV-0233-P). (A-F) Isolated metapodials in dorsal (A,C,E) and ventral (B,D,F) views. (G-U) Articulated elements in dorsal $(\mathbf{G}, \mathbf{M}, \mathbf{Q}, \mathbf{T})$, ventral $\mathbf{( H , J , N , P , S ) , ~ l e f t ~ l a t e r a l ~} \mathbf{( I , R )}$ and right lateral $\mathbf{( L , O}, \mathbf{O})$ views. (J-L) Pollex, composed of a metacarpal, a proximal/basal phalanx and a distal/ungual phalanx. mc, metacarpal; mph, middle phalanx; pph, proximal phalanx; uph, ungual phalanx.

Provelosaurus americanus: sagittal ones, being more circular and having a weak boss with a small central concavity; and lateral osteoderms (Figures 13B-E), oval and smaller than the former, lacking the central concavity. The largest osteoderms were reported to be located at the first dorsal vertebrae [sagittal osteoderm: $37 \times 32 \mathrm{~mm}$, lateral osteoderm: $28 \times 17 \mathrm{~mm}$ (AraújoBarberena, 1987), Figure 1A]. The scutes in UFRGS-PV-359-P contrast in both size and morphology, as in the new fossil the smaller scute is circular and the largest are oval, and all lack the central concavities. Based on these discrepancies, we interpret that these osteoderms are not related to the vertebral column but rather to the cervical ribs to which they are still in contact with. The new fossils, thus, indicate that osteoderms covered the lateral surfaces of the neck. There is yet no indication that osteoderms were present over the girdles, limbs or the remaining ribs in the Brazilian pareiasaur. Is not unlikely, however, that osteoderms covered a broader area of the body, because these small elements may easily detach due to postmortem factors.

\section{DISCUSSION}

\section{Phylogenetic Relationships}

The first analysis produced 600 most parsimonious trees (MPT) and a tree score of 275 steps. The topology of the majority rule consensus (Tree 1 in Supplementary Material) does not differ from the results obtained by Liu and Bever (2018, 5a) except for the placement of Shihtienfenia permica, which in our analysis is not grouped with the 'dwarf pareiasaurs' but rather with the genus Pareiasuchus, and for the position of Nochelesaurus alexanderi, which is now basal to Bradysaurus baini rather than in a polytomy. Removing Obirkovia gladiator 


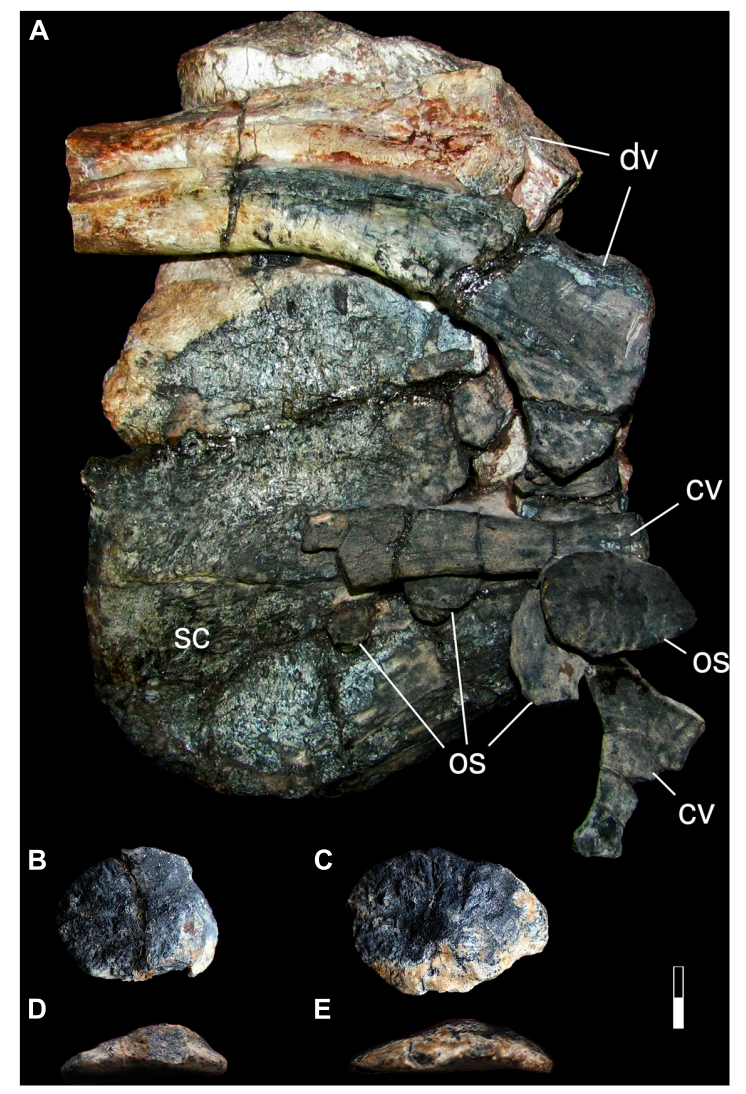

FIGURE 13 | Osteoderms of Provelosaurus americanus.

(A) UFRGS-PV-0359-P, partial scapulocoracoid in medial view, with attached ribs and osteoderms. (B-D) UFRGS-PV-0233-P, lateral osteoderms from top of the vertebrae in $\mathbf{( B , C )}$ dorsal and $\mathbf{( D , E )}$ ?lateral views. Scale bar represents $15 \mathrm{~mm}$ for (A) and $10 \mathrm{~mm}$ for (B-E). cv, cervical rib; dv, dorsal rib; os, osteoderm; sc, scapulocoracoid.

in the second analysis reduced the number of MPT to 414 but retained a tree length of 275 . The only topological change in the majority rule consensus (Tree 2 in Supplementary Material) in relation to the first analysis is in the Elginiidae sensu Liu and Bever (2018), which loses Arganaceras vacanti from Morocco as one of its members, being now formed exclusively by the two Elginia species. Removing Sanchuansaurus pygmaeus instead of Obirkovia gladiator produced only 200 MPT with a tree score of 271. The majority consensus is presented in Figure 14 (Tree 3 in Supplementary Material). In all three analyses, Provelosaurus americanus is recovered within the 'dwarf pareiasaurs' or Pumiliopareiasauria sensu Jalil and Janvier (2005), forming a trichotomy with Nanoparia luckhoffi and the Anthodon serrarius-Pumiliopareia pricei dichotomy. Our results contrast with those presented by Van den Brandt et al. (2019) in which the dwarf pareiasaurs do not form a clade and, on the other hand, the Tapinocephalus Assemblage Zone pareiasaurs do form a natural group. These authors, however, focused only on cranial characters, which explains the absence of Pumiliopareia, a clade largely based on postcranial features. Although the overall support for the tree is low, our results confirm previous studies
(Lee, 1997b; Jalil and Janvier, 2005; Tsuji and Müller, 2008; Tsuji, 2013; Tsuji et al., 2013; Turner et al., 2015; Benton, 2016; Liu and Bever, 2018) that found the Brazilian taxon to be a 'dwarf pareiasaur', being by far the oldest member (see below) of this Gondwanan clade. This relationship has been traditionally supported by features of the humerus but it is now based on two non-ambiguous cranial character states as well, being the absence of a cingulum (72:0) and the tabular-parietal contact on the skull roof (142:1). At the time of submitting the final version of our manuscript we had access to a study by Van den Brandt et al. (accepted) which further confirms the placement of Provelosaurus americanus within Pumiliopareia.

\section{The Age of the Brazilian Pareiasaur}

The presence of temnospondyls and pareiasaurs at the Aceguá area originally led Barberena et al. (1985) to propose the Aceguá Local Fauna, which would be correlated to the Lopingian Daptocephalus Assemblage Zone of the South African Karoo Basin due the common occurrence of the genus originally identified as Pareiasaurus (Araújo, 1985b; Barberena et al., 1985) in Brazil. In this framework, the Aceguá Local Fauna would be younger than the Endothiodon-bearing Serra do Cadeado Local Fauna (this one correlated to the Cistecephalus Assemblage Zone) found in the northern Paraná Basin (Barberena et al., 1985; Boos et al., 2015). The reassignment of the Brazilian pareiasaur to a new genus (Provelosaurus) by Lee (1997a), in addition to the discovery of dinocephalians (Langer, 2000) and the platyoposaur temnospondyl Bageherpeton longignathus (Dias and Barberena, 2001) in the same geological unit (but see below), however, precipitated some controversies regarding the age of the Rio do Rasto Formation in the state of Rio Grande do Sul. Dinocephalians are known exclusively from Guadalupian rocks (Kammerer, 2011; Rubidge et al., 2019) and platyoposaur-like temnospondyls are restricted to Sakmarian-Wordian deposits (Eltink et al., 2019). It is worth mentioning that these taxa were originally recorded at different outcrops in Aceguá and São Gabriel municipalities (Figure 1). This fact, combined with the geography in southern Brazil, which is characterized by a vegetation cover that separates small rock exposures, makes it difficult to make local correlations and renders the possibility of different ages for these fossil sites.

Provelosaurus americanus is the only tetrapod species recorded in both Aceguá and São Gabriel (Figure 1). In the latter, it co-occurs with anteosaurid and tapinocephalid dinocephalians [Langer, 2000; Cisneros et al., 2005; Boos et al., 2015; Figures 1C (site 4), 2D]. The presence of dinocephalians in this assemblage indicates an age not younger than late Guadalupian, which is now supported by a geochronological date (266.7 \pm 5.4 Ma; Rocha-Campos et al., 2019) obtained from the ashfall layer found only $2 \mathrm{~m}$ below the putative level in which one of the Provelosaurus americanus specimens was found (see Figures 1B (site 7), 2B). Considering the broad error margin, this radiometric dating places the Provelosaurusbearing faunas within the early Roadian-middle Capitanian interval. The remaining tetrapods of the Morro Pelado Member fauna in Rio Grande do Sul, however, suggest an age not older than Wordian. Tapinocephalids are known elsewhere only in 


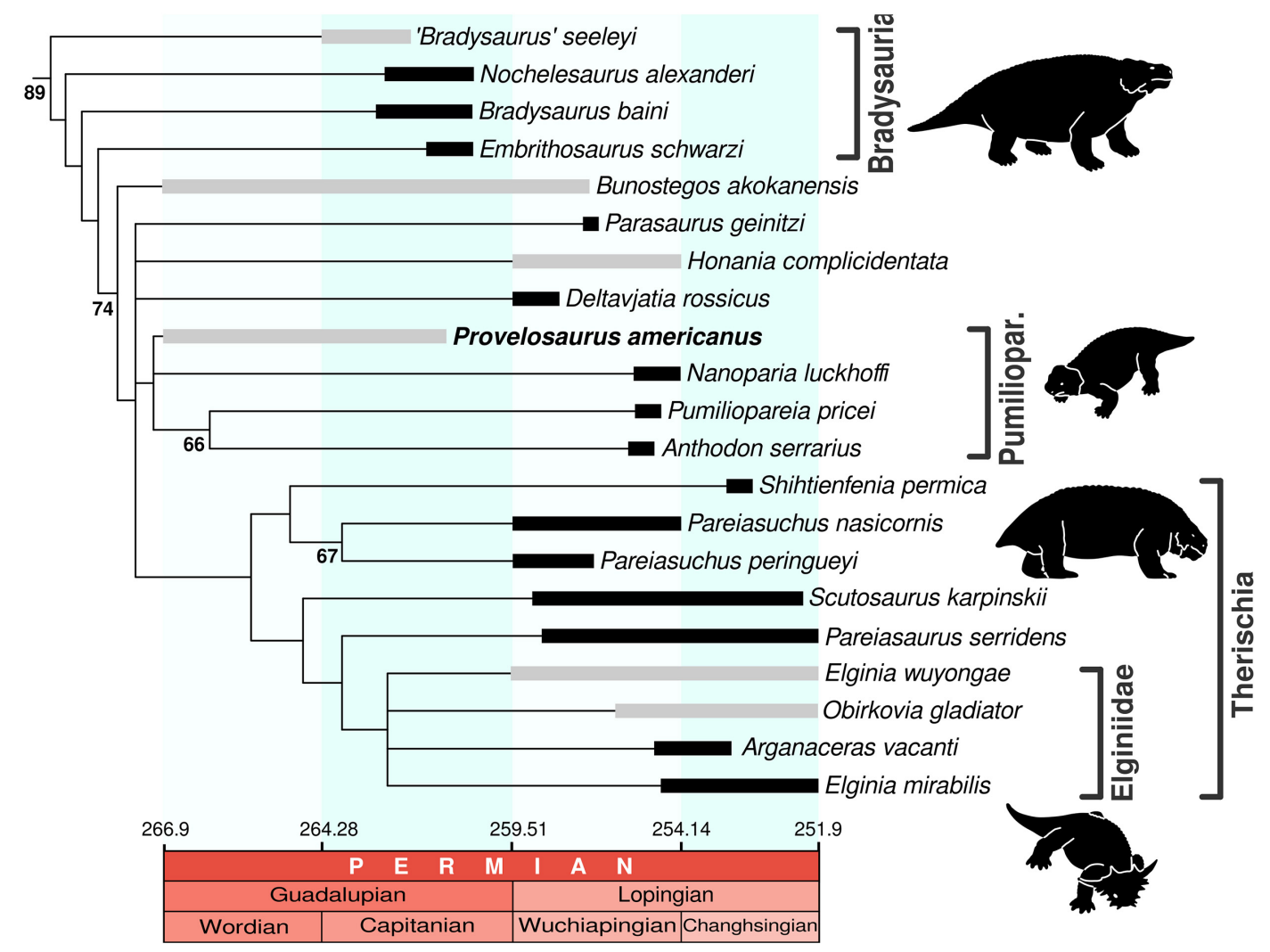

FIGURE 14 | Stratigraphically calibrated relationships of Pareiasauria. Majority rule consensus of 200 MPT (tree score: 270) excluding Sanchuansaurus pygmaeus. Numbers behind nodes represent symmetric resampling values above $50 \%$ (calculated from 5000 replicates, $p=33$ ). Pareiasaur occurrences/ranges based on Jalil and Janvier (2005), Tsuji and Müller (2008), Liu et al. (2014), Benton (2016), Olroyd and Sidor (2017), Sennikov and Golubev (2017), Liu and Bever (2018), Day and Rubidge (2020), Day and Smith (2020), Schneider et al. (2020), Smith (2020), Smith et al. (2020), and Viglietti (2020). Dates after Cohen et al. (2021). Pumiliopar, Pumiliopareiasauria ("dwarf pareiasaurs"). Bradysauria sensu Van den Brandt et al. (2019), Pumiliopareiasauria and Therischia sensu Jalil and Janvier (2005), Elginiidae sensu Liu and Bever (2018). Gray bars indicate ranges with high uncertainty.

Wordian and Capitanian rocks (Rubidge and Day, 2020; Day and Rubidge, 2021), the basal anomodont Tiarajudens eccentricus is closely related to Anomocephalus africanus (see Cisneros et al., 2015) from the upper Tapinocephalus Assemblage Zone, and the temnospondyl genus Konzhukovia, recently identified at the Boqueirão Farm in São Gabriel (Pacheco et al., 2017), is restricted to the Wordian-Capitanian interval in the Russian Platform. Nevertheless, the Brazilian pareiasaur would be older than the Karoo "dwarf pareiasaurs" and at least as old as the three pareiasaur genera from the Tapinocephalus Assemblage Zone and Bunostegos akokanensis from the Moradi Formation of Niger (Olroyd and Sidor, 2017; Figure 14).

The long-snouted temnospondyl Bageherpeton longignathus, known from an incomplete lower jaw from Aceguá (Dias and Barberena, 2001), is an enigmatic taxon that has not been found associated with pareiasaurs nor dinocephalians. Although reportedly collected in the Rio do Rasto Formation, the precise stratigraphic context of this fossil was not provided by the authors. Furthermore, the site that produced this fossil (site 1 in Figure 1B) currently exposes the Teresina Formation (Serviço Geológico do Brasil - CPRM, 2021). This suggests that this platyoposaur was likely collected in a lower geological unit, either in the Serrinha Member of the Rio do Rasto Formation or in the Teresina Formation. A geochronological date for the Serrinha Member was recently obtained $(270.61+1.76 /-$ 3.27 Ma; Francischini et al., 2018), from an outcrop (site 8 in Figure 1B) located $6.5 \mathrm{~km}$ north of the Provelosaurus americanus type locality. Xenacanthus santosi, a chondrichthyan found in the Bageherpeton longignathus site (Würdig-Maciel, 1975), is also recorded in an outcrop of the Teresina Formation at the Tiarajú District in São Gabriel (Klein, 1999), reinforcing the second hypothesis. In either scenario, Bageherpeton longignathus would be in a stratigraphically lower position than the tetrapods from the Morro Pelado member.

\section{Taphonomy and Paleoecology}

With the exception of the partial skull MCP 4263PV from São Gabriel municipality, all remaining six Provelosaurus americanus specimens were recovered in the Aceguá area. Four individuals of different ontogenetic stages were found in a area of less than $100 \mathrm{~m}^{2}$ : two adults (UFRGS-PV-0231-P and UFRGS-PV-0358P) and two small juveniles (UFRGS-PV-0232-P and UFRGSPV-0376-P) were collected from the type locality; a sub-adult 
(UFRGS-PV-0233-P) $600 \mathrm{~m}$ south; and one adult (UFRGSPV-0359-P) in the Santo Antônio Farm, $5 \mathrm{~km}$ to the east. Unfortunately we cannot confirm that UFRGS-PV-0233-P came from the same stratigraphic horizon as the four specimens from the type exposure because, despite its close proximity, both road cuts are two small to allow a confident correlation. For the same reasons, we cannot correlate these exposures with the skeleton found at Santo Antônio Farm.

Even if we cannot confirm that all Aceguá pareiasaurs are within the same stratigraphic horizon, it is still a good question why six individuals from the same species, including juveniles and adults, but no other tetrapods yet, were found in such a small area. This occurrence becomes more remarkable when considering the modern geography of the region, being largely covered by permanent vegetation and crops, with only very small, human-made exposures available for fossil searching, suggesting that the amount of fossils present in the area could be considerably higher than what is detectable under current circumstances. The fossils at the type locality (UFRGS-PV-0231P, UFRGS-PV-0232-P, UFRGS-PV-0358, and UFRGS-PV-0376) occur within a massive siltstone package. Apart from lithostatic compression, they are well preserved. None of the fossils exhibits a high fragmentation degree (apart from some of the teeth) nor intense reworking. Also, with a possible exception of one bone in UFRGS-PV-359-P, there are no biting traces that could indicate the action of carnivores/scavengers on the carcasses. On the other hand, all these four specimens show some degree of disarticulation. The type skull was in situ (Figure 4C) and the humerus and pectoral girdle were ex situ with no other skeletal parts found (Araújo, 1985b). However, considering that the type was found in a road cut, it cannot be discarded that a more complete skeleton was originally preserved but lost during the opening of the road. The Santo Antônio Farm specimen, also an adult, includes cranial and postcranial bones that were found ex situ, which were presumably in articulation before being damaged by human activity, as shown by several recent fractures. The postcranium UFRGS-PV-0233-P, is the only nonadult found articulated. On the other hand, the young-adult skull UFRGS-PV-0376-P and the small scapulocoracoid described here (UFRGS-PV-0358-P), were in situ and completely isolated from other skeletal elements, as is the case of the juvenile pelvis, UFRGS-PV-0232-P, described by Araújo (1986b). In short, based on all taphonomic signatures mentioned above, there is no strong evidence of a long-distance transportation or a long-term exposition, and the disarticulation degree can be, at least to some degree, related to the age of the individual.

There are no reported concentrations of pareiasaur remains elsewhere in the world except in the Kotel'nich assemblage of the Russian Lopingian. The exceptionally rich deposit along the Vyatka River has produced nearly 150 individuals of the midsized pareiasaur Deltavjatia rossicus over a century of studies (Benton et al., 2012; Tsuji, 2013) and also an aggregation of 15 individuals of the therapsid anomodont Suminia getmanovi (see Fröbisch and Reisz, 2009) among other numerous tetrapods. The Kotel'nich pareiasaurs are preserved sitting in a series of mudstone-filled scours cut into a dark red, calcrete-bearing palaeosol surface, in a series of mudstone-filled scours, and

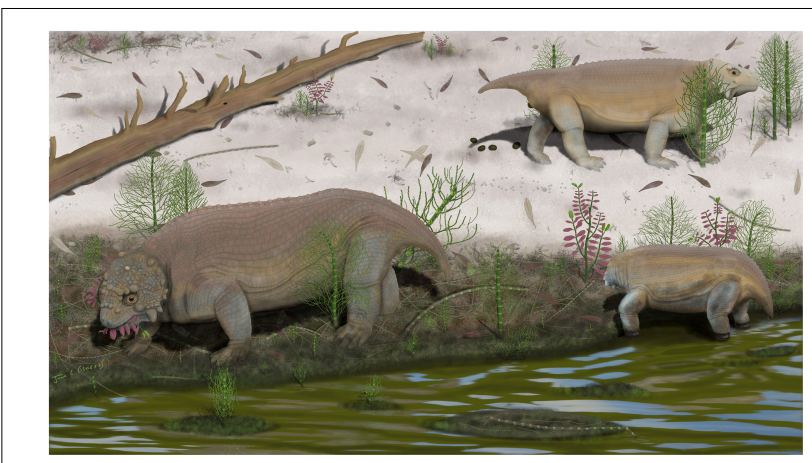

FIGURE 15 | Life reconstruction of Provelosaurus americanus in its habitat. Plant genera represented are Glossopteris, Paracalamitina, and Schizoneura. Art by JCC.

apparently were searching for water in a time of catastrophic aridification, dying, weakened, and mired in soft sediment (Benton et al., 2012).

Such a scenario can be readily discarded for the Provelosaurus americanus concentration of Aceguá. However, an environmental stress event may have been the cause of death of these animals too. Furthermore, the association of four individuals of different ontogenetic stages at the small type exposure suggests at least some degree of gregariousness for the Brazilian species (Figure 15). With seven individuals so far, the fast-growing tetrapod Provelosaurus americanus (e.g., Farias et al., 2021), is the most abundant terrestrial herbivore of the Rio Grande do Sul Guadalupian. This is in contrast with the remaining herbivorous vertebrates of this fauna, represented by single-fossil finds so far (Langer, 2000; Cisneros et al., 2015; Boos et al., 2016). Pareiasaurs also occur in large numbers in other basins, as demonstrated by the track record, especially in the Lopingian Arenaria di Val Gardena and Bellerophon formations of the northeastern Italian Alps. In these units, the pareiasaur-related ichnospecies Pachypes dolomiticus is found at several horizons and constitutes about 38\% of the ichnoassociations (Citton et al., 2016; Bernardi et al., 2017). Although Provelosaurus americanus co-occurs with tapinocephalid dinocephalians in São Gabriel, the abundance of pareiasaurs in Aceguá could be related to niche partitioning, as proposed for the Capitanian megaherbivores of the Karoo Basin (Canoville et al., 2014), but more evidence is needed to support this model in the Permian of southern Brazil.

\section{CONCLUSION}

Provelosaurus americanus is the most common fossil tetrapod in the Morro Pelado Member of the Rio do Rasto Formation in southern Brazil. New specimens complemented previous finds and allowed to produce a rather complete osteological account of the only known South American pareiasaur. Radiometric dating and coeval fauna indicate that Provelosaurus americanus is one of the oldest known pareiasaurs. The platyoposaur temnospondyl Bageherpeton longignathus likely belongs to a lower stratigraphic unit and is older than the Brazilian pareiasaur. 
Phylogenetic analysis reinforces that Provelosaurus americanus is closely related to the Karoo "dwarf pareiasaurs" from which it is separated by a long ghost lineage. The Brazilian pareiasaur was likely a gregarious species, as indicated by an association of mixed-aged individuals.

\section{DATA AVAILABILITY STATEMENT}

The original contributions presented in the study are included in the article/Supplementary Material, further inquiries can be directed to the corresponding author/s.

\section{AUTHOR CONTRIBUTIONS}

JCC conceived and designed the project. All the authors did fieldwork, analyzed the data, prepared the figures, and wrote the manuscript.

\section{FUNDING}

Work funded by a CNPq grant (302936/2018-1) to PD-D, and a FAPERGS grant (21/2551-0000734-6) to HF.

\section{REFERENCES}

Araújo, D. C. F. (1985b). Sobre Pareiasaurus americanus sp. nov., do Permiano Superior do Rio Grande do Sul, Brasil. I-Diagnose específica. An. Acad. Bras. Ciênc. 57, 63-66.

Araújo, D. C. F. (1985a). Estudo do material sul-americano de Pareiasauroidea: II Descrição osteológica de crânio de Pareiasaurus americanus. An. Acad. Bras. Ciênc. 57, 67-85.

Araújo, D. C. F. (1986a). Estudo do material Sul-Americano de Pareiasauroidea. III: Descrição osteológica da escápula-coracóide de Pareiasaurus americanus. An. Acad. Bras. Ciênc. 58, 379-385.

Araújo, D. C. F. (1986b). Estudo do material sul-americano de Pareiasauroidea. IV: Descrição osteológica do propódio e epipódio dos membros anterior e posterior de Pareiasaurus americanus. An. Acad. Bras. Ciênc. 58, 387-401.

Araújo-Barberena, D. C. (1987). Armadura osteodérmica de Pareiasaurus americanus Araújo 1985 (Cotylosauria, Procolophonia, Pareiasauroidea) do Permiano Superior do Rio Grande do Sul. Paula Coutiana 1, 11-16.

Araújo-Barberena, D. C. (1989a). Estudo do material Sul-Americano de Pareiasauroidea. V: Descrição da pelvis de Pareiasaurus americanus Araújo, 1985. An. Acad. Bras. Ciênc. 61, 285-294.

Araújo-Barberena, D. C. (1989b). Estudo do material Sul-Americano de Pareiasauroidea. VI: Descrição do esqueleto axial de Pareiasaurus americanus Araújo, 1985. An. Acad. Bras. Ciênc. 12, 295-309.

Barberena, M. C. (1998). Australerpeton cosgriffi n.g., n.sp., a Late Permian rhinesuchoid amphibian from Brazil. An. Acad. Bras. Ciênc. 70, 125-137.

Barberena, M. C., Araújo, D. C., and Lavina, E. L. (1985). Late Permian and Triassic tetrapods of southern Brazil. Natl. Geogr. Res. 1, 5-20.

Benton, M. J. (2016). The Chinese pareiasaurs. Zool. J. Linn. Soc. 177, 813-853. doi: 10.1111/zoj.12389

Benton, M. J., Newell, A. J., Khlyupin, A. Yu, Shumov, I. S., Price, G. D., and Kurkin, A. A. (2012). Preservation of exceptional vertebrate assemblages in Middle Permian fluviolacustrine mudstones of Kotel'nich, Russia: stratigraphy, sedimentology, and taphonomy. Palaeogeo. Palaeoclim. Palaeoecol. 319-320, 58-83. doi: 10.1016/j.palaeo.2012.01.005

Bernardi, M., Petti, F. M., Kustatscher, E., Franz, M., Hartkopf-Fröder, C., Labandeira, C. C., et al. (2017). Late Permian (Lopingian) terrestrial ecosystems:

\section{ACKNOWLEDGMENTS}

We acknowledge Roberto Cardozo (Santo Antonio Farm), Patrícia Camargo (Type locality) and Modesto Spencer Fagundes and his family for allowing fieldwork at their properties. Ana de Oliveira Bueno (UFRGS) did fossil preparation and drawings (Figures 9, 10). Voltaire Paes Neto (UFRGS) did additional preparation. We acknowledge Marc Van den Brandt (University of the Witwatersrand), Liu Jun (Institute of Vertebrate Paleontology and Paleoanthropology, Beijing) and Elena Boyarinova (Borissiak Paleontological Institute of Russian Academy of Sciences) for discussion. Domingas M. da Conceição (UFRGS) provided advice on Figure 15. We are also greatly indebted to Claudinho (UFRGS), A. E. Quezado (UFPI), and Alexandre Liparini (UFS) for field support.

\section{SUPPLEMENTARY MATERIAL}

The Supplementary Material for this article can be found online at: https://www.frontiersin.org/articles/10.3389/fevo.2021. 758802/full\#supplementary-material

A global comparison with new data from the low-latitude Bletterbach Biota. Earth Sci. Rev. 175, 18-43. doi: 10.1016/j.earscirev.2017.10.002

Boonstra, L. D. (1929a). Pareiasaurian Studies. - Part III. — On the Pareiasaurian Manus. Ann. S. Afr. Mus. 28, 97-112.

Boonstra, L. D. (1929b). Pareiasaurian Studies. - Part IV. — On the Pareiasaurian Pes. Ann. S. Afr. Mus. 28, 113-122.

Boonstra, L. D. (1932). Pareiasaurian studies. Part VIII - The osteology and myology of the locomotor apparatus. B - Forelimb. Ann. S. Afr. Mus 17, 437-503.

Boonstra, L. D. (1934a). Pareiasaurian studies. Part IX - The cranial osteology. Ann. S. Afr. Mus. 31, 1-38.

Boonstra, L. D. (1934b). Pareiasaurian studies. Part X - The dermal armour. Ann. S. Afr. Mus. 31, 39-48.

Boonstra, L. D. (1934c). Pareiasaurian studies. Part XI — The Vertebral Column and Ribs. Ann. S. Afr. Mus. 31, 49-66.

Boos, A. D. S., Kammerer, C. F., Schultz, C. L., and Paes Neto, V. D. (2015). A tapinocephalid dinocephalian (Synapsida, Therapsida) from the Rio do Rasto Formation (Paraná Basin, Brazil): Taxonomic, ontogenetic and biostratigraphic considerations. J. South Am. Earth Sci. 63, 375-384. doi: 10.1016/j.jsames.2015. 09.003

Boos, A. D. S., Kammerer, C. F., Schultz, C. L., Soares, M. B., and Ilha, A. L. R. (2016). A new dicynodont (Therapsida: Anomodontia) from the Permian of Southern Brazil and Its implications for bidentalian origins. PLoS One 11:e0155000. doi: 10.1371/journal.pone.0155000

Boos, A. D. S., Schultz, C. L., Vega, C. S., and Aumond, J. J. (2013). On the presence of the Late Permian dicynodont Endothiodon in Brazil. Palaeontology 56, 837-848. doi: 10.1111/pala.12020

Broom, R. (1903). On an almost perfect skeleton of Pareiasaurus serridens Owen. Ann. S. Afri. Mus. 4, 123-138.

Broom, R., and Robinson, J. T. (1948). Two new cotylosaurian reptiles. Ann. Transvaal Mus. 21, 51-54.

Bulanov, V. V., and Yashina, O. V. (2005). Elginiid pareiasaurs of Eastern Europe. Paleontol. J. 39, 428-432.

Canoville, A., Thomas, D. B., and Chinsamy, A. (2014). Insights into the habitat of Middle Permian pareiasaurs (Parareptilia) from preliminary isotopic analyses. Lethaia 47, 266-274. doi: 10.1111/let.12056 
Cisneros, J. C. (2008). Phylogenetic relationships of procolophonid parareptiles with remarks on their geological record. J. Syst. Palaeontol. 6, 345-366. doi: $10.1017 /$ S1477201907002350

Cisneros, J. C., Abdala, F., Atayman-Guven, S., Rubidge, B. S., Sengor, A. M. C., and Schultz, C. L. (2012). Carnivorous dinocephalian from the Middle Permian of Brazil and tetrapod dispersal in Pangaea. Proc. Nat. Acad. Sci. U.S.A. 109, 1584-1588. doi: 10.1073/pnas.1115975109

Cisneros, J. C., Abdala, F., Jashashvili, T., de Oliveira Bueno, A., and Dentzien-Dias, P. (2015). Tiarajudens eccentricus and Anomocephalus africanus, two bizarre anomodonts (Synapsida, Therapsida) with dental occlusion from the Permian of Gondwana. R. Soc. Open Sci. 2:150090. doi: 10.1098/rsos.150090

Cisneros, J. C., Abdala, F., and Malabarba, M. C. (2005). Pareiasaurids from the Rio do Rasto Formation, southern Brazil: biostratigraphic implications for Permian faunas of the Paraná Basin. Rev. Bras. Paleontol. 8, 13-24.

Cisneros, J. C., Abdala, F., Rubidge, B. S., Dentzien-Dias, P. C., and Bueno, A. D. O. (2011). Dental occlusion in a 260-million-year-old therapsid with saber canines from the Permian of Brazil. Science 331, 1603-1605. doi: 10.1126/science. 1200305

Citton, P., Nicolosi, I., Carluccio, R., and Nicosia, U. (2016). Unveiling trampling history through trackway interferences and track preservational features: a case study from the Bletterbach gorge (Redagno, Western Dolomites, Italy). Palaeontol. Electron 2:19. doi: 10.26879/611

Cohen, K. M., Finney, S. C., Gibbard, P. L., and Fan, J.-X. (2021). The ICS International Chronostratigraphic Chart - v 2021/07 36: 199-204. Available online at: http://www.stratigraphy.org/ICSchart/ChronostratChart2021-07.pdf (accessed August 12, 2021).

Day, M. O., Ramezani, J., Bowring, S. A., Sadler, P. M., Erwin, D. H., Abdala, F., et al. (2015). When and how did the terrestrial mid-Permian mass extinction occur? Evidence from the tetrapod record of the Karoo Basin, South Africa. Proc. R. Soc. Lond. B. 282:20150834. doi: 10.1098/rspb.2015.0834

Day, M. O., and Rubidge, B. S. (2020). Biostratigraphy of the Tapinocephalus Assemblage Zone (Beaufort Group, Karoo Supergroup), South Africa. S. Afr. J. Geol. 123, 149-164. doi: 10.25131/sajg.123.0012

Day, M. O., and Rubidge, B. S. (2021). The Late Capitanian mass extinction of terrestrial vertebrates in the Karoo Basin of South Africa. Front. Earth Sci. 9:631198. doi: 10.3389/feart.2021.631198

Day, M. O., and Smith, R. M. H. (2020). Biostratigraphy of the Endothiodon Assemblage Zone (Beaufort Group, Karoo Supergroup), South Africa. S. Afr. J. Geol. 123, 165-180. doi: 10.25131/sajg.123.0011

deBraga, M. (2003). The postcranial skeleton, phylogenetic position, and probable lifestyle of the Early Triassic reptile Procolophon trigoniceps. Can. J. Earth Sci. 40, 527-556. doi: 10.1139/e02-082

Dentzien-Dias, P. C., de Figueiredo, A. E. Q., Horn, B., Cisneros, J. C., and Schultz, C. L. (2012). Paleobiology of a unique vertebrate coprolites concentration from Rio do Rasto Formation (Middle/Upper Permian), Paraná Basin, Brazil. J. South Am. Earth Sci. 40, 53-62. doi: 10.1016/j.jsames.2012.09.008

Dias, E. V., and Barberena, M. C. (2001). A temnospondyl amphibian from the Rio do Rasto Formation, Upper Permian of southern Brazil. An. Acad. Bras. Ciênc. 73, 135-143. doi: 10.1590/S0001-37652001000100011

Dias, E. V., Dias-da-Silva, S., and Schultz, C. L. (2020). A new short-snouted rhinesuchid from the Permian of southern Brazil. Rev. Bras. Paleontol. 23, 98-122. doi: 10.4072/rbp.2020.2.03

Dias-Da-Silva, S. (2012). Middle-Late Permian tetrapods from the Rio do Rasto Formation, Southern Brazil: a biostratigraphic reassessment: Permian tetrapod biostratigraphy, Brazil. Lethaia 45, 109-120. doi: 10.1111/j.1502-3931.2011. 00263.x

Eltink, E., Schoch, R. R., and Langer, M. C. (2019). Interrelationships, palaeobiogeography and early evolution of Stereospondylomorpha (Tetrapoda: Temnospondyli). J. Iber. Geol. 45, 251-267. doi: 10.1007/s41513-019-00105-z

Farias, B. D. M., Schultz, C. L., and Soares, M. B. (2021). Bone microstructure of the pareiasaur Provelosaurus americanus from the Middle Permian of southern Brazil. Hist. Biol. 33, 328-339. doi: 10.1080/08912963.2019.1617288

Francischini, H., Dentzien-Dias, P., Guerra-Sommer, M., Menegat, R., Santos, J. O. S., Manfroi, J., et al. (2018). A middle Permian (Roadian) lungfish aestivation burrow from the Rio do Rasto Formation (Paraná Basin, Brazil) and associated U-Pb dating. Palaios 33, 69-84. doi: 10.2110/palo.2017.050

Fröbisch, J., and Reisz, R. R. (2009). The Late Permian herbivore Suminia and the early evolution of arboreality in terrestrial vertebrate ecosystems. Proc. R. Soc. Lond. B. 276, 3611-3618. doi: 10.1098/rspb.2009.0911
Goloboff, P. A., and Catalano, S. A. (2016). TNT version 1.5, including a full implementation of phylogenetic morphometrics. Cladistics 32, 221-238. doi: $10.1111 /$ cla. 12160

Gordon, M. Jr. (1947). Classification of the Gondwanic rocks of Paraná, Santa Catarina, and Rio Grande do Sul. Departamento Nacional da Produção Mineral $38,1-20$.

Hamley, T., Cisneros, J. C., and Damiani, R. (2021). A procolophonid reptile from the Lower Triassic of Australia. Zool. J. Linn. Soc. 192, 554-609. doi: 10.1093/ zoolinnean/zlaa056

Haughton, S. H., and Boonstra, L. D. (1930a). Pareiasaurian studies. Part V - On the pareiasaurian mandible. Ann. S. Afr. Mus. 28, 79-87.

Haughton, S. H., and Boonstra, L. D. (1930b). Pareiasaurian studies. Part VI - The osteology and myology of the locomotor apparatus. A. Hind limb. Ann. S. Afr. Mus. 28, 297-367.

Holz, M., França, A. B., Souza, P. A., Iannuzzi, R., and Rohn, R. (2010). A stratigraphic chart of the Late Carboniferous/Permian succession of the eastern border of the Paraná Basin, Brazil, South America. J. South Am. Earth Sci. 29, 381-399. doi: 10.1016/j.jsames.2009.04.004

Ivakhnenko, M. F. (1987). Permian parareptiles of the USSR. Trudy Paleontologicheskogo Instituta Akademii Nauk SSSR 223, 1-159.

Jalil, N.-E., and Janvier, P. (2005). Les pareiasaures (Amniota, Parareptilia) $\mathrm{du}$ Permien supérieur du Bassin d'Argana, Maroc. Geodiversitas 27, 35-132.

Kammerer, C. F. (2011). Systematics of the Anteosauria (Therapsida: Dinocephalia). J. Syst. Palaeontol. 9, 261-304. doi: 10.1080/14772019.2010. 492645

Kern, H. P., Lavina, E. L. C., Paim, P. S. G., Girelli, T. J., and Lana, C. (2021). Paleogeographic evolution of the southern Paraná Basin during the Late Permian and its relation to the Gondwanides. Sediment. Geol. 415:105808. doi: 10.1016/j.sedgeo.2020.105808

Klein, C. (1999). Fácies sedimentares e observações bioestratinômicas das concentrações fossilíferas da Formação Teresina na região de Tiaraju, RS, Brasil. Acta Geol. Leopold. 23, 75-92.

Langer, M. C. (2000). The first record of dinocephalians in South America: Late Permian (Rio do Rasto Formation) of the Paraná Basin, Brazil. Neues Jahrb. Geol. Palaontol. Abh. 215, 69-95. doi: 10.1127/njgpa/215/2000/69

Laurenti, J. N. (1768). Classis Reptilium. Specimen medicum: exhibens synopsis reptilium emendatam cum experimentis circa venena et antidota reptilium austriacorum. Washington, DC, USA: Joan Thomae, Vienna.

Lee, M. S. Y. (1997a). A taxonomic revision of pareiasaurian reptiles: implications for Permian terrestrial palaeoecology. Mod. Geol. 21, 231-298.

Lee, M. S. Y. (1997b). Pareiasaur phylogeny and the origin of turtles. Zool. J. Linn. Soc. 120, 197-280. doi: 10.1111/j.1096-3642.1997.tb01279.x

Lee, M. S. Y., Gow, C. E., and Kitching, J. W. (1997). Anatomy and relationships of the pareiasaur Pareiasuchus nasicornis from the Upper Permian of Zambia. Palaeontology 40, 307-335.

Leonardi, P., Conti, M. A., Leonardi, G., Mariotti, N., and Nicosia, U. (1974). Pachypes dolomiticus n. gen. n. sp.; pareiasaur footprint from the "Val Gardena Sandstone" (Middle Permian) in the western Dolomites (N. Italy). Atti Accad. Naz. Lincei Cl. Sci. Fis. Mat. Natur. Rend. Ser. 8, 221-232.

Li, X.-W., and Liu, J. (2013). New specimens of pareisarus from the Upper Permian Sunjiagou Formation of Liulin, Shanxi and their implications for the taxonomy of Chinese pareiasaurs. Vert. PalAs. 51, 199-204.

Liu, J., and Bever, G. S. (2018). The tetrapod fauna of the upper Permian Naobaogou Formation of China: a new species of Elginia (Parareptilia, Pareiasauria). Pap. Palaeontol. 4, 197-209. doi: 10.1002/spp2.1105

Liu, J., Xu, L., Jia, S.-H., Pu, H.-Y., and Liu, X.-L. (2014). The Jiyuan tetrapod fauna of the Upper Permian of China-2. stratigraphy, taxonomical review, and correlation. Vert. PalAs. 52, 328-339.

Maddison, W. P., and Maddison, D. R. (2019). Mesquite: A Modular System for Evolutionary Analysis. Available online at: http://www.mesquiteproject.org (accessed January 21, 2021).

Maisch, M. W., and Matzke, A. T. (2019). Anthodon haughtoni (v. Huene, 1944), a pareiasaurid (Parareptilia: Pareiasauria) from the Late Permian Usili Formation of Kingori, Ruhuhu Basin, Tanzania. Neues Jahrb. Geol. Palaontol. Abh. 291, 197-204. doi: 10.1127/njgpa/2019/0796

Malabarba, M. C., Abdala, F., Weiss, F. E., and Perez, P. A. (2003). New data on the Late Permian vertebrate fauna of Posto Queimado, Rio do Rasto Formation, southern Brazil. Rev. Bras. Paleontol. 6, 49-54. 
Martinelli, A. G., Francischini, H., Dentzien-Dias, P. C., Soares, M. B., and Schultz, C. L. (2017). The oldest archosauromorph from South America: postcranial remains from the Guadalupian (mid-Permian) Rio do Rasto Formation (Paraná Basin), southern Brazil. Hist. Biol. 29, 76-84. doi: 10.1080/08912963.2015. 1125897

Milani, E. J., Melo, J. H. G., Souza, P. A., Fernandes, L. A., and França, A. B. (2007). Bacia do Paraná. B. Geoci. Petrobras. 15, 265-287.

Olroyd, S. L., and Sidor, C. A. (2017). A review of the Guadalupian (middle Permian) global tetrapod fossil record. Earth Sci. Rev. 171, 583-597. doi: 10. 1016/j.earscirev.2017.07.001

Olson, E. C. (1947). The family Diadectidae and its bearing on the classification of reptiles. Field. Geol. 11, 1-53. doi: 10.5962/bhl.title.3579

Pacheco, C. P., Eltink, E., Müller, R. T., and Dias-da-Silva, S. (2017). A new Permian temnospondyl with Russian affinities from South America, the new family Konzhukoviidae, and the phylogenetic status of Archegosauroidea. J. Syst. Palaeontol. 15, 241-256. doi: 10.1080/14772019.2016.1164763

Pauliv, V. E., Martinelli, A. G., Francischini, H., Dentzien-Dias, P., Soares, M. B., Schultz, C. L., et al. (2017). The first Western Gondwanan species of Triodus Jordan 1849: A new Xenacanthiformes (Chondrichthyes) from the late Paleozoic of Southern Brazil. J. South Am. Earth Sci. 80, 482-493. doi: 10.1016/j.jsames.2017.09.007

Rocha-Campos, A. C., Basei, M. A. S., Nutman, A. P., Santos, P. R., Passarelli, C. R., Canile, F. M., et al. (2019). U-Pb zircon dating of ash fall deposits from the Paleozoic Paraná Basin of Brazil and Uruguay: a reevaluation of the stratigraphic correlations. J. Geol. 127, 167-182. doi: 10.1086/70 1254

Romano, M., Manucci, F., Rubidge, B., and Van den Brandt, M. J. (2021). Volumetric body mass estimate and in vivo reconstruction of the Russian pareiasaur Scutosaurus karpinskii. Front. Ecol. Evol. 9:692035. doi: 10.3389/fevo. 2021.692035

Rubidge, B. S. (2005). 27th Du Toit Memorial Lecture: Re-uniting lost continents Fossil reptiles from the ancient Karoo and their wanderlust. S. Afri. J. Geol. 108, 135-172. doi: 10.2113/108.1.135

Rubidge, B. S., and Day, M. O. (2020). Biostratigraphy of the Eodicynodon Assemblage Zone (Beaufort Group, Karoo Supergroup), South Africa. S. Afri. J. Geol. 123, 141-148. doi: 10.25131/sajg.123.0010

Rubidge, B. S., Erwin, D. H., Ramezani, J., Bowring, S. A., and de Klerk, W. J. (2013). High-precision temporal calibration of Late Permian vertebrate biostratigraphy: U-Pb zircon constraints from the Karoo Supergroup, South Africa. Geology 41, 363-366. doi: 10.1130/G33622.1

Rubidge, B. S., Govender, R., and Romano, M. (2019). The postcranial skeleton of the basal tapinocephalid dinocephalian Tapinocaninus pamelae (Synapsida: Therapsida) from the South African Karoo Supergroup. J. Syst. Palaeontol. 17, 1767-1789. doi: 10.1080/14772019.2018.1559244

Schneider, J. W., Lucas, S. G., Scholze, F., Voigt, S., Marchetti, L., Klein, H., et al. (2020). Late Paleozoic-early Mesozoic continental biostratigraphy - Links to the Standard Global Chronostratigraphic Scale. Palaeoworld 29, 186-238. doi: 10.1016/j.palwor.2019.09.001

Seeley, H. G. (1888). III. Croonian lecture.-Researches on the structure, organization, and classification of the fossil Reptilia.-II. On Pareiasaurus bombidens (Owen), and the significance of its affinities to Amphibians, Reptiles, and Mammals. Phil. Trans. R. Soc. Lond. B. 179, 59-109. doi: 10.1098/rstb.1888. 0003

Sennikov, A. G., and Golubev, V. K. (2017). Sequence of Permian tetrapod faunas of eastern Europe and the Permian-Triassic ecological crisis. Paleontol. J. 51, 600-611. doi: 10.1134/S0031030117060077

Serviço Geológico do Brasil - CPRM (2021). GeoSBG 2021. SH.21-Z-D-VI-2 Colonia Nova. GeoSBG. Available online at: https://geoportal.cprm.gov.br/ geosgb/? extent $=-6033306.8101 \% 2 \mathrm{C}-3708385.7391 \% 2 \mathrm{C}-6020255.1875 \% 2 \mathrm{C}-$ 3702404.5416\%2C102100 (accessed August 9, 2021).

Silva, R. C., da, Sedor, F. A., and Fernandes, A. C. S. (2012). Fossil footprints from the Late Permian of Brazil: An example of hidden biodiversity. J. South Am. Earth Sci. 38, 31-43. doi: 10.1016/j.jsames.2012.05.001

Smith, R. M. H. (2020). Biostratigraphy of the Cistecephalus Assemblage Zone (Beaufort Group, Karoo Supergroup), South Africa. S. Afr. J. Geol. 123, 181-190. doi: 10.25131/sajg.123.0013

Smith, R. M. H., Rubidge, B. S., Day, M. O., and Botha, J. (2020). Introduction to the tetrapod biozonation of the Karoo Supergroup. S. Afr. J. Geol. 123, 131-140. doi: 10.25131/sajg.123.0009
Spencer, P. S., and Lee, M. S. Y. (2000). A juvenile Elginia and early growth in pareiasaurs. J. Paleontol. 74, 1191-1195. doi: 10.1017/S002233600001773X

Strapasson, A., Pinheiro, F., and Soares, M. (2014). On a new Stereospondylomorpha temnospondyl from the Middle/Late Permian of Southern Brazil. APP 60, 843-855. doi: 10.4202/app.00059.2014

Tsuji, L. A. (2006). Cranial anatomy and phylogenetic affinities of the Permian parareptile Macroleter poezicus. J. Vertebr. Paleontol. 26, 849-865. doi: 10.1671/ $0272-4634200626$

Tsuji, L. A. (2013). Anatomy, cranial ontogeny and phylogenetic relationships of the pareiasaur Deltavjatia rossicus from the Late Permian of central Russia. Earth Environ. Sci. Trans. R. Soc. Edinb. 104, 81-122. doi: 10.1017/ S1755691013000492

Tsuji, L. A., and Müller, J. (2008). A re-evaluation of Parasaurus geinitzi, the first named pareiasaur (Amniota. Parareptilia). Can. J. Earth Sci. 45, 1111-1121. doi: 10.1139/E08-060

Tsuji, L. A., Sidor, C. A., Steyer, J.-S., Smith, R. M. H., Tabor, N. J., and Ide, O. (2013). The vertebrate fauna of the Upper Permian of Niger-VII. Cranial anatomy and relationships of Bunostegos akokanensis (Pareiasauria). J. Vertebr. Paleontol. 33, 747-763. doi: 10.1080/02724634.2013.739537

Turner, M. L., Tsuji, L. A., Ide, O., and Sidor, C. A. (2015). The vertebrate fauna of the upper Permian of Niger-IX. The appendicular skeleton of Bunostegos akokanensis (Parareptilia: Pareiasauria). J. Vertebr. Paleontol. 35:e994746. doi: 10.1080/02724634.2014.994746

Van den Brandt, M. J., Abdala, F., Benoit, J., Michael, O., Day, and Rubidge, B. S. (accepted). Taxonomy, phylogeny and stratigraphic ranges of middle Permian pareiasaurs from the Karoo Basin of South Africa. J. Syst. Palaeont.

Van den Brandt, M. J., Abdala, F., and Rubidge, B. S. (2019). Cranial morphology and phylogenetic relationships of the Middle Permian pareiasaur Embrithosaurus schwarzi from the Karoo Basin of South Africa. Zool. J. Linn. Soc. 64:zlz064. doi: 10.1093/zoolinnean/zlz064

Xu, L., Li, X.-W., Jia, S.-H., and Liu, J. (2014). The Jiyuan tetrapod fauna of the Upper Permian of China-1. New pareiasaur materials and the reestablishment of Honania complicidentata. Acta Palaeontol. Pol. 60, 689-700. doi: 10.4202/ app.00035.2013

Van den Brandt, M. J., Benoit, J., Abdala, F., and Rubidge, B. S. (2021a). Postcranial morphology of the South African middle Permian pareiasaurs from the Karoo Basin of South Africa. Palaeont. Afr. 55, 1-91.

Van den Brandt, M. J., Rubidge, B. S., Benoit, J., and Abdala, F. (2021b). Cranial morphology of the middle Permian pareiasaur Nochelesaurus alexanderi from the Karoo Basin of South Africa. Earth Environ. Sci. Trans. R. Soc. Edinb 112, 1-21. doi: 10.1017/S1755691021000049

Viglietti, P. A. (2020). Biostratigraphy of the Daptocephalus Assemblage Zone (Beaufort Group, Karoo Supergroup), South Africa. S. Afr. J. Geol. 123, 191-206. doi: $10.25131 /$ sajg.123.0014

Würdig-Maciel, N. L. (1975). Ichtiodontes e Ichitiodorulitos (Pisces) da Formação Estrada Nova e Sua Aplicação na Estratigrafia do Grupo Passa Dois. Pesq. Geoc. 5:7. doi: 10.22456/1807-9806.21830

Zerfass, H., Lavina, E. L., Schultz, C. L., Garcia, A. J. V., Faccini, U. F., and Chemale, F. (2003). Sequence stratigraphy of continental Triassic strata of Southernmost Brazil: a contribution to Southwestern Gondwana palaeogeography and palaeoclimate. Sediment. Geol. 161, 85-105. doi: 10.1016/S0037-0738(02) 00397-4

Conflict of Interest: The authors declare that the research was conducted in the absence of any commercial or financial relationships that could be construed as a potential conflict of interest.

Publisher's Note: All claims expressed in this article are solely those of the authors and do not necessarily represent those of their affiliated organizations, or those of the publisher, the editors and the reviewers. Any product that may be evaluated in this article, or claim that may be made by its manufacturer, is not guaranteed or endorsed by the publisher.

Copyright (c) 2021 Cisneros, Dentzien-Dias and Francischini. This is an open-access article distributed under the terms of the Creative Commons Attribution License (CC BY). The use, distribution or reproduction in other forums is permitted, provided the original author(s) and the copyright owner(s) are credited and that the original publication in this journal is cited, in accordance with accepted academic practice. No use, distribution or reproduction is permitted which does not comply with these terms. 